\title{
B-Type Natriuretic Peptide as a Significant Brain Biomarker for Stroke Triaging Using a Bedside Point-of-Care Monitoring Biosensor
}

\author{
Dorin Harpaz ${ }^{1,2, *(\mathbb{D})}$, Raymond C. S. Seet ${ }^{3}$, Robert S. Marks ${ }^{2}$ and Alfred I. Y. Tok ${ }^{1}$ (C) \\ 1 School of Material Science \& Engineering, Nanyang Technology University, 50 Nanyang Avenue, \\ Singapore 639798, Singapore; miytok@ntu.edu.sg \\ 2 Department of Biotechnology Engineering, Ben-Gurion University of the Negev, Beer-Sheva 84105, Israel; \\ rsmarks@bgu.ac.il \\ 3 Division of Neurology, Department of Medicine, Yong Loo Lin School of Medicine, \\ National University of Singapore, NUHS Tower Block, 1E Kent Ridge Road, Singapore 119228, Singapore; \\ mdcrscs@nus.edu.sg \\ * Correspondence: harpaz.dorin@gmail.com or dorinha@post.bgu.ac.il
}

Received: 13 July 2020; Accepted: 24 August 2020; Published: 26 August 2020

\begin{abstract}
Stroke is a widespread condition that causes 7 million deaths globally. Survivors suffer from a range of disabilities that affect their everyday life. It is a complex condition and there is a need to monitor the different signals that are associated with it. Stroke patients need to be rapidly diagnosed in the emergency department in order to allow the admission of the time-limited treatment of tissue plasminogen activator (tPA). Stroke diagnostics show the use of sophisticated technologies; however, they still contain limitations. The hidden information and technological advancements behind the utilization of biomarkers for stroke triaging are significant. Stroke biomarkers can revolutionize the way stroke patients are diagnosed, monitored, and how they recover. Different biomarkers indicate different cascades and exhibit unique expression patterns which are connected to certain pathologies in the human body. Over the past decades, B-type natriuretic peptide (BNP) and its derivative N-terminal fragment (NT-proBNP) have been increasingly investigated and highlighted as significant cardiovascular biomarkers. This work reviews the recent studies that have reported on the usefulness of BNP and NT-proBNP for stroke triaging. Their classification association is also presented, with increased mortality in stroke, correlation with cardioembolic stroke, and an indication of a second stroke recurrence. Moreover, recent scientific efforts conducted for the technological advancement of a bedside point-of-care (POC) device for BNP and NT-proBNP measurements are discussed. The conclusions presented in this review may hopefully assist in the major efforts that are currently being conducted in order to improve the care of stroke patients.
\end{abstract}

Keywords: stroke; diagnostics; biomarker; b-type natriuretic peptide; point-of-care; biosensor

\section{Introduction}

Stroke is a leading cause of death that causes 7 million deaths globally [1]. It occurs as a result of an acute interruption in the brain blood flow [2]. This interference is either due to ischemic stroke (blockage) in $87 \%$ of cases, or due to haemorrhagic stroke (bleeding) in the remaining $13 \%$ of cases $[3,4]$. Stroke patients suffer from a range of disabilities that affect their everyday life [1,5]. Stroke is a complex condition and there is a need to monitor the different signals that are associated with it [6]. For example, in the 90 days prior to the stroke event, patients usually suffer from transient ischemic attacks (TIAs) [7]. In this period, there are significant approaches that can be used in order to reduce the risk of stroke [8]. The most common causes for stroke and TIA are embolic or thrombotic consequences 
of atherothrombotic disease [9]. They share several risk factors, including dietary factors, physical inactivity, excessive alcohol intake, obesity, diabetes, smoking, dyslipidaemia, and hypertension [10]. Individuals of any age can suffer from a stroke; however, it is most common in the elderly population ( $>65$ years) $[11,12]$. Brain changes related to aging have been linked to stroke; moreover, stroke mechanisms differ between young and elderly patients [13]. Together with the growth of the aging population, stroke prevalence and costs will significantly rise in the following years [14-16]. A stroke victim is also considered to be in an increased health risk for heart function, breathing abnormalities, body temperature control, and paralysis [6]. Stroke patient recovery ranges from months at best but can take years, which increases the burden and costs on the healthcare system in developed countries worldwide [14-16].

The identification of patients with acute stroke in the emergency department (ED) is necessary [17] in order to deliver therapies with time-limited treatment, including intravenous and intra-arterial tissue plasminogen activator (tPA) [18-23]. Brain cells die rapidly after stroke; therefore, therapeutic treatment needs to be administered early. The 'time-outcome' effect is highly important in stroke monitoring [24-27] due to the association of time delays with worse patient outcomes [28-30]. The most common modality for evaluation of suspected stroke patients is magnetic resonance imaging (MRI) or computed tomography (CT), which are mainly used to exclude intra-cerebral hemorrhage but have poor sensitivity for detecting acute ischemia. Limitations also include availability, costs, and radiation exposure $[4,31,32]$. Stroke diagnostics show the use of sophisticated technologies; however, they still contain limitations [33]. The widely used stroke scoring systems, such as the National Institutes of Health Stroke Scale (NIHSS) [34,35], are not able to distinguish patients with acute stroke from those with mimic presentations, such as metabolic disorders, migraines, and mass brain lesions [36]. Poor stroke diagnostics results in both pre-hospital and ED time delays in stroke care [37]. Approximately 30\% of patients that were initially suspected to have a stroke are eventually diagnosed with an unrelated condition [38]. Moreover, $50 \%$ of stroke cases are missed [39-42]. A second priority for stroke patients' care is to improve the patient's recovery after stroke. There are approximately 30 million stroke survivors globally, and they comprise approximately one-quarter of the residents in long-term care (LTC) facilities. The care for stroke survivors in LTC facilities is lacking in rehabilitation, stroke-specific care, and secondary stroke prevention [43]. Additionally, it is necessary to continue in follow-up examinations, which are essential for coordinating post-acute services and monitoring of the patient's progress [44]. In order to improve the acute ischemic stroke diagnostic, a potential strategy is to measure the serum levels of brain-injury-related biochemical biomarkers [45,46]. In addition, there is a need for an improved recovery approach and the use of biomarkers has promising results [47].

The hidden information and technological advancements behind the utilization of biomarkers for stroke triaging are significant [48-50]. Stroke biomarkers can revolutionize the way that stroke patients are diagnosed, monitored, and how they recover [51-53]. Different biomarkers indicate different cascades and exhibit unique expression patterns that are connected to certain pathologies in the human body [46,54,55]. A biomarker should be specific (reflect the extent of brain damage), sensitive (easily detected), and selective (reflect therapeutic efficacy) [56,57]. Stroke is associated with a variety of pathophysiological changes, which lead to the triggering of different biochemical processes and related biomarkers [58-70]. Over the past decades, B-type natriuretic peptide (BNP) and its derivative $\mathrm{N}$-terminal pro-BNP (NT-proBNP) have been increasingly investigated and highlighted as significant cardiovascular biomarkers, especially for heart failure (HF) and recently also for stroke [71,72]. The biochemistry of BNP expression is presented in Figure 1. BNP is also referred to as uretic peptide or ventricular natriuretic peptide. It is a 32-amino acid long cyclic polypeptide with the ring structure confined between cysteine in positions 10 and 26. It is secreted by the heart ventricles as a result of excessive stretching of cardiomyocytes (heart muscle cells) [73]. Although BNP was discovered in porcine brain, subsequent studies revealed that in humans, BNP is most abundantly expressed in the heart [74]. Recent studies have shown that proBNP is glycosylated, which results in the inhibition of processing of proBNP by protease (e.g., furin or corin). Therefore, the concentration of proBNP in the 
blood is higher than of BNP [75]. BNP release is also regulated by calcium ions. The biologically active BNP is secreted together with the biologically inactive 76-amino acid NT-proBNP peptide. Similarly to atrial natriuretic peptide (ANP), BNP binds and activates the atrial natriuretic peptide receptors NPRA, but with 10-fold lower affinity [76]. However, the biological half-life of ANP is half of that of BNP, and NT-proBNP has an even longer half-life time, making both BNP and NT-proBNP better candidates for a diagnostic device. BNP accurately reflects current ventricular status, as its half-life is $20 \mathrm{~min}$, as opposed to 1-2 $\mathrm{h}$ for NT-proBNP [77]. The timeline of the research developments on natriuretic peptides is presented in Figure 2. This work reviews the recent studies that have reported on the usefulness of BNP and NT-proBNP for stroke triaging. Then, their association is presented with increased mortality in stroke, correlation with cardioembolic stroke, and an indication of second stroke recurrence. Moreover, the recent scientific efforts conducted for the technological advancements in a bedside point-of-care (POC) device for BNP and NT-proBNP measurements are discussed.

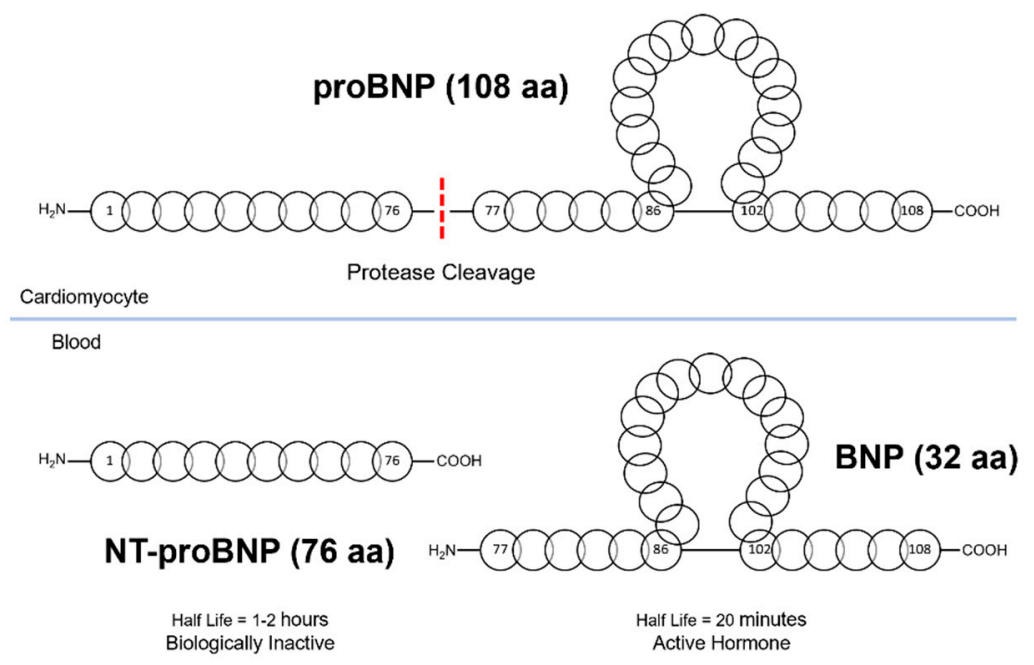

Figure 1. The biochemistry of B-Type natriuretic peptide expression.

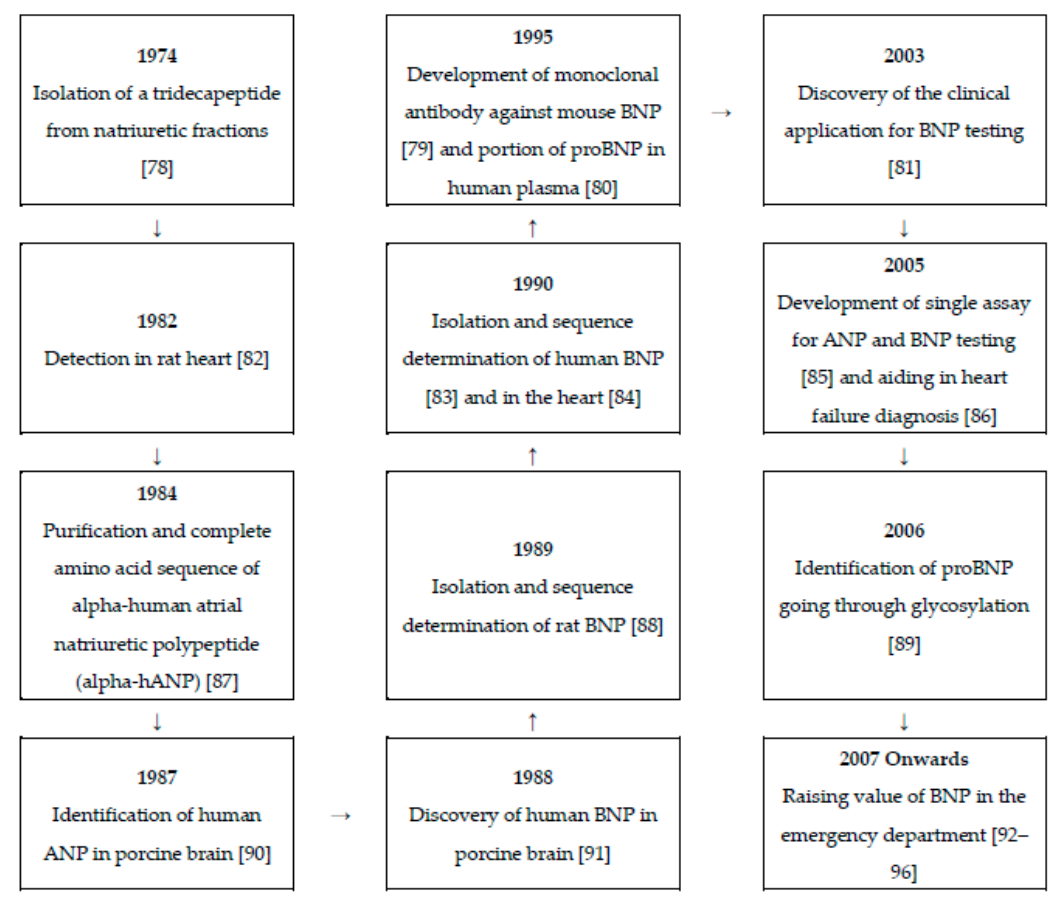

Figure 2. Timeline of the research developments on natriuretic peptides [78-96]. 


\section{B-Type Natriuretic Peptide Expression in Stroke Pathology}

\subsection{Association with Increased Mortality in Stroke}

BNP plasma and NT-proBNP serum levels are elevated in stroke pathology (Table 1) and associated with increased mortality [97-108]. Montaner J. et al. [104] identified that BNP plasma levels were higher among patients who died (118.2 vs. $60.9 \mathrm{pg} / \mathrm{mL} ; p<0.001)$, and multivariate logistic regression analysis indicated that the plasma BNP level was an independent predictor of death after stroke $(\mathrm{BNP}>65.3 \mathrm{pg} / \mathrm{mL}$; odds ratio $(\mathrm{OR})=1.97 ; p=0.034)$. Chen $\mathrm{X}$. et al. [103] reported that NT-proBNP levels in the deceased group $(3280 \mathrm{pg} / \mathrm{mL})$ were significantly $(p<0.001)$ higher than in the survival group (926.30 pg/mL). García-Berrocoso T. et al. [97] concluded that BNP is associated with post-stroke mortality independent of the NIH stroke scale score, age, and sex. However, their translation to clinical practice seems difficult because BNP and NT-proBNP add only minor predictive value to clinical information. Shibazaki K. et al. [100] concluded that plasma BNP > 100.0 pg/mL (OR, 3.94; $95 \%$ confidence intervals (CI), 2.31-6.73, $p<0.001$ ) were found to be independently associated with long-term mortality. Sayan S. and Kotan D. [106] concluded that plasma BNP levels were increased in the acute phase of stroke and can be used as a biomarker for mortality. Li J. et al. [103] and Bunevicius A. et al. [107] identified that the level of NT-proBNP was positively correlated with the National Institutes of Health Stroke Scale score and stroke severity, respectively.

\subsection{Correlation with Cardioembolic Stroke}

Ischemic stroke is subclassified into different etiologies, which includes atherosclerosis, cardioembolic, lacunar, others [109], and undetermined cases [110]. They differ in their underlying mechanisms behind the stroke event [111-113]. The most commonly used classification scheme is the Trial of Org 10,172 in Acute Stroke Treatment (TOAST) classification [114-117]. Stroke etiology classification's main value is for therapeutic decision-making in order to reduce the time to IV-tPA admission [109]. The average time is $3 \mathrm{~h}$ from stroke symptoms, and it was found to be useful only when administered within $4.5 \mathrm{~h}[18,19]$. However, ischemic stroke etiologies' classification schemes are complex, time-consuming (between hours to days), and require professional personnel. Therefore, over the past years, different biomarkers have been examined for use in ischemic stroke etiology classification [49]. Several recent studies concluded that BNP and NT-proBNP elevated serum levels show a correlation with cardioembolic stroke [118-140]. In addition, BNP and NT-proBNP showed correlation with an atrial fibrillation (AF) condition, abnormal heart rhythm (arrhythmia), that was found to be associated with cardioembolic stroke. In AF, the source of increased plasma BNP could be due to an enlarged atrium [141]. Llombart V. et al. [119] reported that the blood levels of both BNP and NT-proBNP are significantly higher in cardioembolic stroke up to $72 \mathrm{~h}$ after symptoms onset, with a sensitivity $>90 \%$ and specificity $>80 \%$. Yang H.-1. et al. [118] reported that the cardioembolic subgroup analysis showed that NT-proBNP had a slightly higher specificity and better capability for exclusion diagnosis. Kawase S. et al. [120] examined the correlations between plasma BNP level and conventional risk factors for ischemic stroke. The results showed that the mean plasma level of BNP was significantly higher for cardioembolic $(366.6 \mathrm{pg} / \mathrm{mL})$ than for non-cardioembolic $(105.6 \mathrm{pg} / \mathrm{mL}$; $p<0.01)$.

Moreover, in a study by Kara K. et al. [126], BNP distinguished the incidence of cardioembolic stroke. Chaudhuri J. R. et al. [122] investigated the association of plasma BNP levels in acute ischemic stroke subtypes and their outcomes. The results showed that among the stroke subtypes, elevated BNP levels were observed in $75 \%$ of cardioembolic stroke patients, $45.8 \%$ of small artery disease patients, $43.1 \%$ of larger artery atherosclerosis patients, and $34.5 \%$ of stroke of undetermined etiology patients. They concluded that an elevated BNP level is an independent marker for cardioembolic stroke and poor outcome at 90 days follow-up after the stroke incident. The same conclusion was received in a study by Cojocaru I. M. et al. [123], which showed that the level of plasma proBNP may be useful in distinguishing cardioembolic stroke from other stroke subtypes. Moreover, Bai J. et al. [133] reported 
that BNP showed a summary sensitivity of 0.65 (95\% CI: $0.63-0.68)$ and a summary specificity of 0.85 (95\% CI: 0.83-0.87). NT-proBNP showed a summary sensitivity of 0.55 (95\% CI: $0.52-0.59$ ) and a summary specificity of 0.93 (95\% CI: 0.91-0.94). Nakamura M. et al. [135] reported that the ability of BNP to predict the incidence of cardioembolic stroke was excellent (area under the curve (AUC)-receiver operating characteristic $(\mathrm{ROC})=0.81)$. Also, when BNP was added to other well-known risk factors, the ability to predict cardioembolic stroke significantly improved: 4-year follow-up, $p=0.018$; 8-year follow-up, $p=0.009$; net reclassification improvement $=0.968, p<0.0001$ : integrated discrimination improvement $=0.039, p<0.05$.

Strengthening these findings, $\mathrm{Wu} \mathrm{Z}$. et al. [121] examined the use of a POC test platform for plasma BNP detection in preliminary recognition of cardioembolic stroke patients in the ED. The results showed that the mean BNP concentration was significantly higher in the cardioembolic group than in the other 3 stroke subtypes: (1) large artery atherosclerosis; (2) small artery occlusion (e.g., lacunar); and (3) stroke of other determined etiology or stroke of other undetermined etiology $(p<0.01)$. The plasma BNP level greater than $66.5 \mathrm{pg} / \mathrm{mL}$ had good corresponding diagnostic performance in the preliminary recognition of cardioembolic stroke patients, with a sensitivity of $75.56 \%$ and a specificity of $87.40 \%$. Their conclusion was that a plasma BNP level greater than $66.5 \mathrm{pg} / \mathrm{mL}$ as a reference index had good corresponding diagnostic performance in the preliminary recognition of cardioembolic stroke patients. However, the single BNP biomarker cannot be used individually to confidently identify the cardioembolic subtype as a diagnosis. In another study by Wu Z. et al. [124], the plasma BNP concentration was measured immediately at the bedside. The target was to recognize the patients with cardioembolic stroke as soon as possible due to high risks and poor long-term outcomes, including mortality risk. They concluded that the BNP testing at bedside upon admission could be suggested as an addition to early stroke management guidelines as a strategy for improving stroke subtype classification, predicting the development of atrial fibrillation after admission, and risk stratification.

\subsection{Indication on Second Stroke Recurrence}

BNP plasma and NT-proBNP serum levels can also indicate second stroke recurrence [142-145]. Shibazaki K. et al. [142] investigated whether BNP levels could be used as a biomarker to predict recurrent stroke in ischemic stroke survivors. Consecutive patients within $24 \mathrm{~h}$ of ischemic stroke symptom onset were prospectively enrolled and admission plasma BNP levels were measured. Survivors were followed for up to 12 months after stroke onset. A total of 793 patients who were alive at hospital discharge included $42(5 \%)$ patients who had a recurrent stroke. There were no differences in BNP levels between the two groups. With respect to 257 patients with AF, BNP levels were significantly higher in the recurrence group than in the non-recurrence group ( $426.0 \mathrm{vs.} 192.0 \mathrm{pg} / \mathrm{mL}, p=0.0007)$. The BNP optimal cutoff level was $>300.0 \mathrm{pg} / \mathrm{mL}$, with $80 \%$ sensitivity and $73 \%$ specificity to distinguish the recurrence group from the non-recurrence group in stroke patients with AF. In another study by the same group, Shibazaki K. et al. [143] examined whether BNP levels are associated with early recurrent stroke in cardioembolic stroke patients. Admission plasma BNP levels were measured. Recurrent stroke was identified as the occurrence of additional neurologic deficits and the appearance of a new infarct on neuroimaging. The results showed that 17 patients $(5 \%)$ had a recurrent stroke during hospitalization. The median interval time from stroke symptom onset to the recurrent stroke event was 4 days (range, $0-30$ ). BNP levels were significantly higher in the recurrence group than in the non-recurrence group ( 304.1 vs. $206.5 \mathrm{pg} / \mathrm{mL}, p=0.029$ ). The BNP optimal cutoff level was $>255.0 \mathrm{pg} / \mathrm{mL}$, with $76 \%$ sensitivity and $60 \%$ specificity to distinguish the recurrence group from the non-recurrence group. They concluded that plasma BNP can be a useful biomarker for predicting early recurrent stroke events during hospitalization in cardioembolic stroke patients. A similar conclusion was also observed in a study by Mortezabeigi H. R. et al. [144], which concluded that BNP is capable of predicting TIA recurrence. Rodríguez-Castro E. et al. [145] reported that a cut-off point of $800 \mathrm{pg} / \mathrm{mL}$ of NT-proBNP predicted stroke with a sensitivity of $64 \%$ and a specificity of $79 \%(p<0.001)$, and was independently associated with a higher risk of stroke after a TIA (OR: 6.65, $p<0.001$ ). 
Table 1. B-type natriuretic peptide association in stroke pathology.

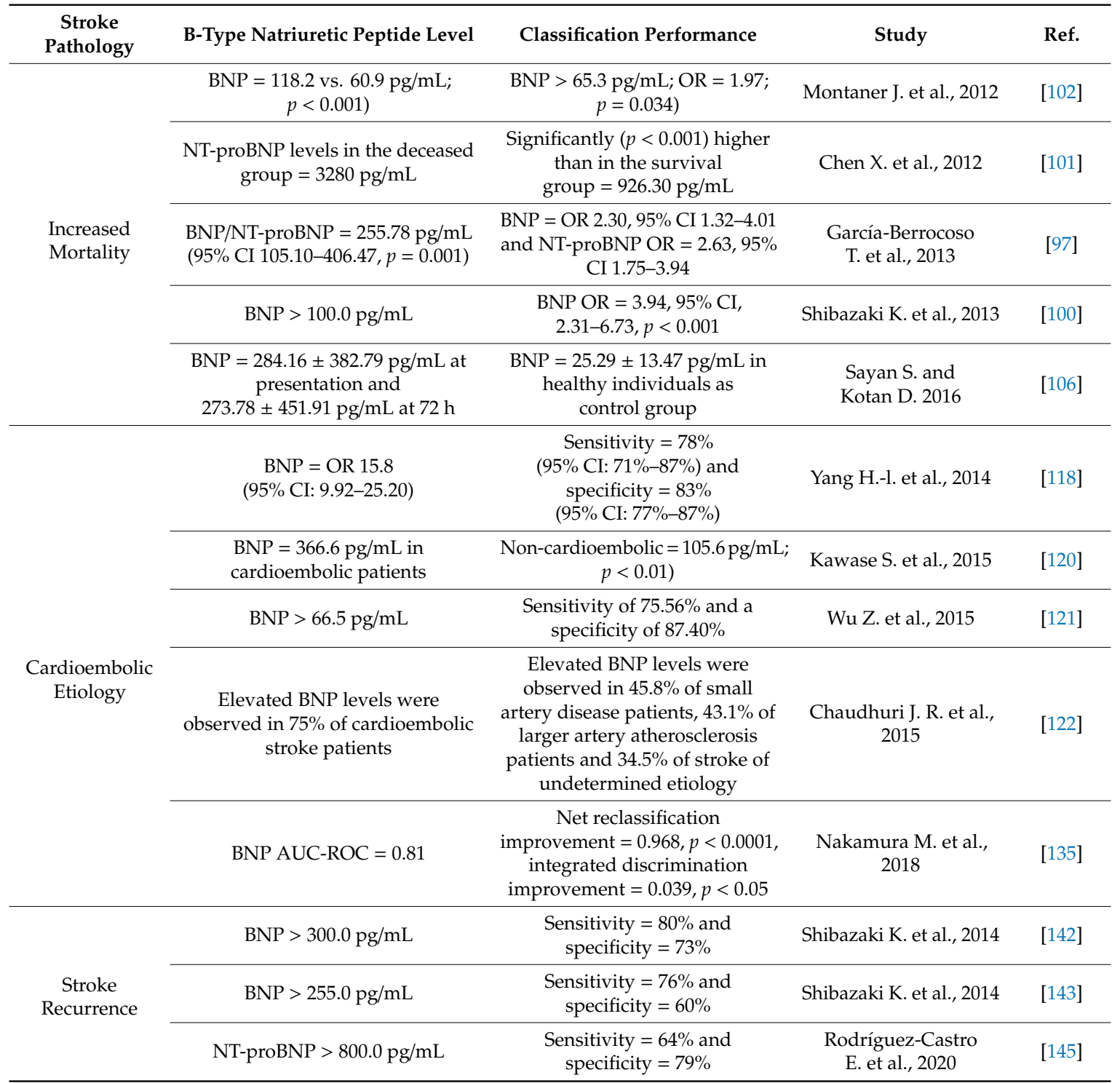

Abbreviations: 95\% confidence interval (95\% CI); odds ratio (OR); area under the curve (AUC); receiver operating characteristic (ROC).

\section{Detection of B-Type Natriuretic Peptides}

\subsection{Point-of-Care Biosensor Platform}

A POC biosensor platform is a rapid test that obtains results within minutes, which is user-friendly, robust, and can be used on-site [146]. Successful examples include the glucometer [147] and lateral flow pregnancy test. These assay platform advantages include mobility, fast data processing, simple measurement, and the small volume of the sample required [148]. The enzyme-linked immunosorbent assay (ELISA) is the most common technology for immunoassay [149], with high sensitivity but complicated with multiple steps. A POC biosensor platform can have sufficient sensitivity while enabling a more practical approach $[150,151]$. It is an integrated biorecognition-transducer device, capable of giving quantitative results [152-154]. It is based on: (1) biorecognition, which allows the detection of target biological molecule; (2) the interface, the system's main structure and function, and (3) the transducer that enables signal measurement and result processing (Figure 3). The choice of the biorecognition element (e.g., antibodies) is made according to the target analyte. Towards the creation of POC assays for commercial applications in healthcare diagnostics, there are constant efforts 
to minimize the size of the assay and still to obtain sensitive and accurate analyte detection, as well as to simplify the fabrication process [155-157]. There is an unmet need for customized POC in stroke care [158-160].

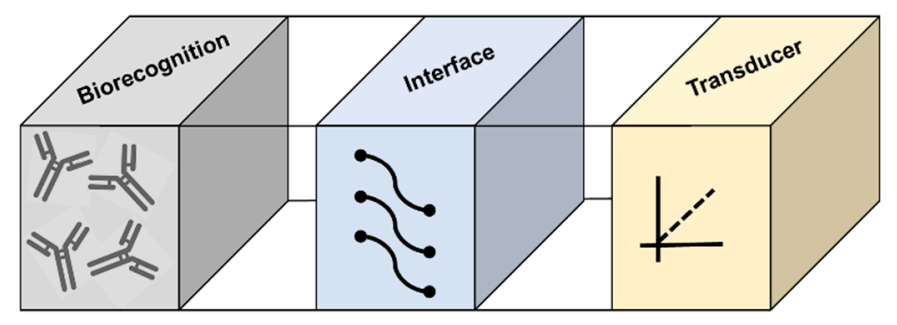

(A)

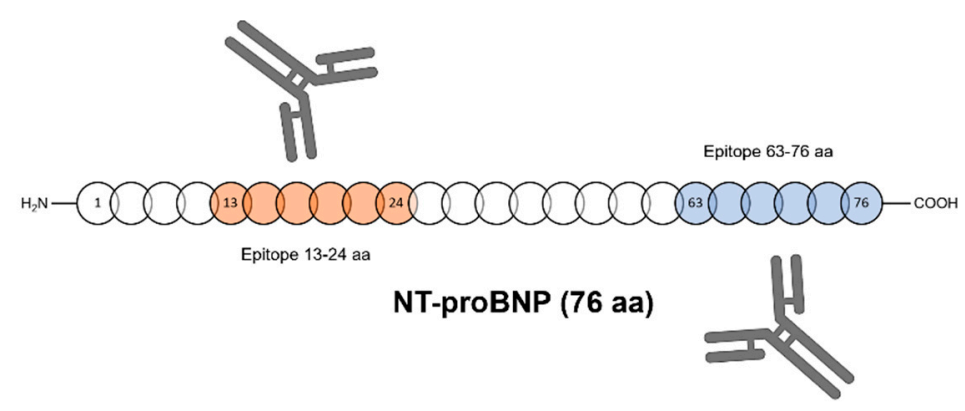

(B)

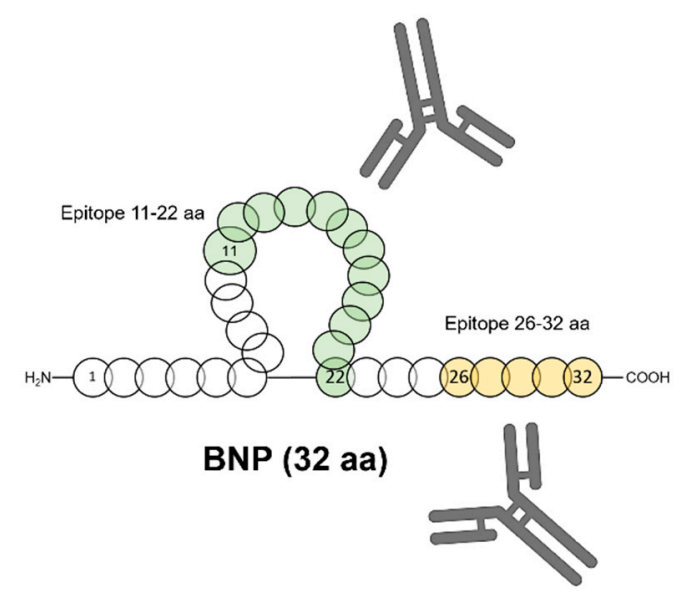

(C)

Figure 3. Detection of B-type natriuretic peptide. (A) Point-of-care biosensor platform; (B) N-terminal pro-B-type natriuretic peptide (NT-proBNP) epitopes (13-24 aa and 63-76 aa); (C) B-type natriuretic peptide (BNP) epitopes (11-22 aa and 26-32 aa).

\subsection{Attractive Epitopes for The Detection of NT-proBNP}

The sensing of b-type natriuretic peptides for clinically useful diagnostic assays demonstrates analytical problems, mainly with circulating NT-proBNP [161], assay specificity, and analyte stability [162-165]. Several previous studies examined the development of NT-proBNP immunoassays [166-168]. There is no consensus on the exact circulating peptides that are derived from proBNP $[80,169,170]$. In addition, it was reported that proBNP undergo O-linked glycosylation [89], which further interferes with antibody recognition [171]. Moreover, molecular heterogeneity was also reported to influence NT-proBNP measurement $[85,172]$. Ala-Kopsala M. et al. examined the use of mass spectrometry to determine 
that even when there is heterogeneity in circulating NT-proBNP, still some specific epitopes of the peptide show higher stability, and therefore are more attractive for immunoassay development [161]. Two of those peptides were identified as NT-proBNP1-36 and NT-proBNP1-62/64; the masking of the NT-proBNP mid-region epitopes is likely due to oligomers that are formed. Most of the antibodies that are used in NT-proBNP immunoassays are directed against its terminal parts [85,173-177]. However, evidence was found that the N-terminus of NT-proBNP is susceptible to modifications that occur in the blood and alter its immune-reactivity $[161,163]$. These modifications may be the reason behind the large variance of circulating NT-proBNP concentrations that are reported by several immunoassays that are directed to its N-terminus [162,164,178,179]. Additionally, Seferian K. R. et al. examined endogenous NT-proBNP by applying multiple immunochemical approaches by using a panel of monoclonal antibodies (MABs) that are specific to different epitopes of the NT-proBNP peptide [171]. It was reported that the C-terminus of NT-proBNP is vulnerable to proteolysis, while the epitopes in its mid-fragment may be concealed by glycosylation. As a result, the mid-fragment of the NT-proBNP peptide is almost invisible for antibody recognition. It was concluded that MAbs specific to the N- and C-terminal parts of NT-proBNP (epitopes 13-24 and 63-76) are the best candidates to be used in an optimal assay for NT-proBNP detection (Figure 3). This conclusion contrasts with the conclusion accepted in the studies that were previously presented, which prioritized the recognition of the central part of the NT-proBNP molecule in order to avoid the blood-modification vulnerability of the non-mid-region epitopes. For example, NT-proBNP is often measured via a sandwich assay. However, NT-proBNP contains seven sites for O-linked glycosylation. Therefore, it is possible that one antibody in the sandwich assay may recognize one of the glycosylation sites. As a result, the serum NT-proBNP levels that are measured in such assay systems might be less accurate. Special attention should be paid to epitope profiling in the design of NT-proBNP assays.

\subsection{Sandwich Immunoassay Formats for the Detection of BNP}

The sensing of BNP is mostly conducted in a sandwich immunoassay format. The majority of the BNP sandwich immunoassays show the use of 2 monoclonal antibodies (MABs) that are specific for different BNP epitopes. One of the MABs is specific for the BNP peptide ring structure and the other $\mathrm{MAB}$ is specific for the $\mathrm{C}$ terminus or the $\mathrm{N}$ terminus of the BNP peptide. However, as previously discussed, both of these binding sites are susceptible to modifications in the blood that also have an influence on their immune reactivity. A study by Tamm N. N. et al. [180] shows the development of a novel BNP and proBNP immunoassay, which is based on a new form of a single epitope sandwich immunoassay. This immunoassay requires only a short BNP11-22 fragment (FGRKMDRISSSS) for the detection (Figure 3). The capture antibody $(\mathrm{Ab})$ recognizes the BNP epitope, whereas the detection antibody is specific to the immune complex of the capture antibody and the BNP peptide (Ab-BNP). It was concluded that the developed single epitope sandwich immunoassay recognized both BNP and proBNP with the same efficiency and sensitivity than conventional sandwich BNP immunoassays. In addition, it demonstrated less susceptibility to antigen degradation. Also, this assay still maintained a short detection time and a broad linearity range $(0.00023-17.6 \mathrm{nmol} / \mathrm{L})$. Moreover, the developed assay was compared with two commercial assays that measure BNP for HF. The first, ARCHITECT ${ }^{\circledR}$ BNP Assay Performance Verification, AACC 2006, uses a capture antibody from Scios (anti-BNP 106.3) that recognizes the ring structure and possibly part of the arm extending to the $C$ terminus, and a detection antibody (anti-BNP BC203) from Shionogi that is specific to the $C$ terminus of the molecule. The second, 50E1-24C5 HyTest in-house BNP assay uses similar epitope specificity of the antibodies. These two monoclonal antibodies, 106.3 and BC203 demonstrate high affinities to BNP and bind two distant epitopes [181].

\subsection{Commercial Immunossays}

BNP is a well-known diagnostic and prognostic biomarker in congestive HF [182]. Over the past decades, several commercial measurement devices for BNP detection in HF were developed 
(Table 2) [183]. In the literature, there are earlier studies that showed the measurement of BNP in three commercial assays: TRIAGE (fully automated immunoassay), IRMA (non-competitive immune-radiometric assay), and RIA (competitive immune-radiometric assay). Del Ry S. et al. [184] compared TRIAGE with IRMA. The TRIAGE method is a non-competitive immune-fluorometric sandwich assay which uses two different binding phases that are specific for two different epitopes of the BNP amino acid chain. A polyclonal antibody is included in the fluorescent immunoassay reagents, which are contained in the assay device, and a monoclonal antibody is immobilized in the detection lane. The mean reading time of the TRIAGE method was $14.5 \pm 8.6 \mathrm{~min}$. The TRIAGE method is used in emergency units, where usually only a few samples must be measured in a short time. The IRMA method is mostly preferred for pathophysiological studies which require the highest degree of precision and sensitivity for simultaneous measurement of several stored plasma samples or tissue extracts. A previous study by Clerico A. et al. [185] compared IRMA with RIA. The IRMA method is based on the solid-phase sandwich system, which uses two monoclonal antibodies prepared against two sterically remote epitopes of the peptide molecule. The first antibody is coated on the beads solid-phase and the second was radio-labeled. The IRMA method showed better sensitivity and a wider working range sensitivity (about $2 \mathrm{ng} / \mathrm{L}$ ) than those of RIA methods. Moreover, the normal range found with these methods was similar to the one generally reported by using the most accurate methods. It was concluded that the IRMA method is preferable for the measurement of plasma BNP for experimental studies and as a routine assay because it is more practical, sensitive, and accurate than RIA procedures.

In addition, Fellner S. et al. [186] evaluated a new POC platform, responss ${ }^{\circledR} I Q$. This assay is an immunoassay platform utilizing evanescent field total internal reflection fluorescence (TIRF) detection and active microfluidics controlled by optical sensors. A BNP assay was developed based on this system. The device consists of a single-use cartridge, which contains all the required biomaterials, as well as an instrument that moves the liquid and controls the microfluidic assay steps with the aid of optical sensors and measures the TIRF assay. In this assay, the limit of detection (LOD) achieved was $2.3 \pm 1 \mathrm{pg} / \mathrm{mL}$ BNP. Ishida J. et al. [187] compared the analytical performance of two single-step measurement POC devices for BNP measurement. The two compared devices were a small-footprint immune-chromatography reader of BNP (Rapidpia ${ }^{\circledR}$ ) and the commercially available SHIONOSPOT ${ }^{\circledR}$ Reader as the index. The Rapidpia ${ }^{\circledR}$ BNP assay demonstrated correlations between whole blood and plasma samples between those with the index SHIONOSPOT ${ }^{\circledR}$ Reader, $y=0.93 x+0.88, R^{2}=0.98$ and $y=1.08 x-6.67, R^{2}=0.93$, respectively. Based on the reported findings, the two POC assays showed comparable results. The main objective of the Rapidpia ${ }^{\circledR}$ test device is to measure BNP rapidly at the patient's home or in the ambulance [188]. In the same study [187], three additional devices were mentioned which are commercially available for the measurement of BNP in Japan: MIO2 $^{\circledR}$ (Shionogi \& Co., Ltd., Osaka, Japan), AIA ${ }^{\circledR}$ (Tosoh Co., Ltd., Tokyo, Japan), and CL-JACK ${ }^{\circledR}$ (Kyowa Medex Co., Ltd., Tokyo, Japan). Additionally, a technology report conducted by Oxford University reviewed POC testing for BNP measurement [189]. Several POC BNP testing devices were identified and they either measure BNP or NT-proBNP. The additional reported devices are as follow: (1) BNP measurement: the Alere Heart Check System (Alere, Stockport, UK). It is a handheld POC sensor that detects BNP from a $15 \mu \mathrm{L}$ blood sample that is obtained by a finger prick. The results are obtained in $15 \mathrm{~min}$. (2) NT-proBNP measurement: the RAMP 200 Clinical System (Response Biomedical, Vancouver, BC, Canada; no UK distributor identified) CE marked. The sensor measures NT-proBNP from an ethylenediaminetetraacetic acid (EDTA) whole blood sample, and the results are obtained in $15 \mathrm{~min}$. The sensor has a reported lower LOD of $18 \mathrm{pg} / \mathrm{mL}$ and an upper limit of linearity of $23,450 \mathrm{pg} / \mathrm{mL}$. The POC sensor weighs approximately $2 \mathrm{~kg}$ and is portable. (3) NT-proBNP measurement: the Cobas h232/Cardiac Reader (Roche Diagnostics, Burgess Hill, UK). It is a handheld sensor POC device that detects NT-proBNP from a $150 \mu \mathrm{L}$ sample of heparinized venous blood. The results are obtained in $12 \mathrm{~min}$. The sensor POC device has a reported lower and upper LOD of $60 \mathrm{pg} / \mathrm{mL}$ and $3000 \mathrm{pg} / \mathrm{mL}$, respectively. 
Table 2. Food and Drug Administration (FDA) approved B-type natriuretic peptide immunoassays.

\begin{tabular}{|c|c|c|c|c|}
\hline $\begin{array}{l}510(K) \\
\text { Number }\end{array}$ & Product & Company & $\begin{array}{l}\text { First Approval } \\
\text { Date }\end{array}$ & $\begin{array}{l}\text { Update Approval } \\
\text { Date }\end{array}$ \\
\hline K873133 & BNP-AMYLASE TEST & SCLAVO INC. & & $10 / 6 / 1987$ \\
\hline K032335 & MAS CARDIOIMMUNE PROBNP & MEDICAL ANALYSIS SYSTEMS INC. & & $8 / 19 / 2003$ \\
\hline K033606 & $\begin{array}{l}\text { ABBOTT AXSYM B-TYPE NATRIURETIC PEPTIDE (BNP) } \\
\text { MICROPARTICLE ENZYME IMMUNOASSAY (MEIA) TEST }\end{array}$ & AXIS-SHIELD DIAGNOSTICS LTD. & & $1 / 30 / 2004$ \\
\hline K043584 & LIQUICHEK BNP CONTROL & BIO-RAD LABORATORIES INC. & & 2/8/2005 \\
\hline K051265 & $\begin{array}{l}\text { ADVIA IMMUNO MODULAR SYSTEM (IMS) B-TYPE } \\
\text { NATRIURETIC PEPTIDE (BNP) ASSAY }\end{array}$ & BAYER HEALTHCARE LLC & $6 / 23 / 2003$ & $6 / 13 / 2005$ \\
\hline K052789 & $\begin{array}{l}\text { TRIAGE BNP TEST FOR BECKMAN COULTER } \\
\text { IMMUNOASSAY SYSTEMS MODEL } 98200\end{array}$ & BIOSITE INCORPORATED & $2 / 29 / 2000$ & $1 / 23 / 2006$ \\
\hline K051596 & $\begin{array}{l}\text { STATUS FIRST CHF (CONGESTIVE HEART FAILURE) } \\
\text { NT-PROBNP MODEL } 20204\end{array}$ & NANOGEN INC. & & $3 / 13 / 2006$ \\
\hline K060964 & ARCHITECT BNP ASSAY MODEL 8K28 & FUJIREBIO DIAGNOSTICS INC. & & $5 / 25 / 2006$ \\
\hline K053597 & I-STAT B-TYPE NATRIURETIC PEPTIDE (BNP) & I-STAT CORPORATION & & $7 / 21 / 2006$ \\
\hline K071834 & $\begin{array}{l}\text { STRATUS CS ACUTE CARE NT-PROBNP TESTPAK } \\
\text { MODEL CPBNPM }\end{array}$ & DADE BEHRING INC. & $2 / 15 / 2005$ & $8 / 17 / 2007$ \\
\hline K072189 & PATHFAST NTPROBNP AND D-DIMER TESTS & MITSUBISHI KAGAKU IATRON & & $2 / 5 / 2008$ \\
\hline K073091 & VIDAS NT-PROBNP ASSAY MODEL 30449 & BIOMERIEUX INC. & & $2 / 29 / 2008$ \\
\hline K080578 & $\begin{array}{c}\text { DIMENSION VISTA N-TERMINAL PRO-BRAIN NATRIURETIC } \\
\text { PEPTIDE (PBNP) FLEX REAGENT CARTRIDGE (K6423A) } \\
\text { DIMENSION VISTA }\end{array}$ & $\begin{array}{l}\text { SIEMENS HEALTHCARE } \\
\text { DIAGNOSTICS INC. }\end{array}$ & $7 / 20 / 2004$ & $5 / 16 / 2008$ \\
\hline K063662 & RAMP NT-PROBNP ASSAY & RESPONSE BIOMEDICAL CORP. & & $7 / 21 / 2008$ \\
\hline K092649 & $\begin{array}{l}\text { ELECSYS PROBNP II STAT IMMUNOASSAY AND ELECSYS } \\
\text { PROBNP II CALSET MODELS 05390109-160 04842472-190 }\end{array}$ & ROCHE DIAGNOSTICS CORP. & $11 / 19 / 2002$ & $2 / 4 / 2010$ \\
\hline
\end{tabular}




\section{Conclusions}

The hidden information and technological advancements behind the utilization of biomarkers for stroke triaging are significant. Stroke biomarkers can revolutionize the way that stroke patients are diagnosed, monitored, and how they recover. Different biomarkers indicate different cascades and exhibit unique expression patterns which are connected to certain pathologies in the human body. Over the past decades, BNP and its derivative NT-proBNP are increasingly investigated and highlighted as significant cardiovascular biomarkers. Previous studies reported on the usefulness of BNP and NT-proBNP for stroke triaging. They showed an association with increased mortality in stroke, correlation with cardioembolic stroke, and indication of second stroke recurrence. Recent scientific efforts have also been conducted for the technological advancement of a bedside POC device for BNP and NT-proBNP measurements. The conclusions discussed in this review may hopefully assist the major efforts that are currently being conducted in order to improve the care for stroke patients. An acronyms summary is presented in Table 3.

Table 3. Acronyms summary.

\begin{tabular}{|c|c|c|}
\hline Number & Acronym & Full Term \\
\hline 1 & $\mathrm{Ab}$ & Antibody \\
\hline 2 & $\mathrm{AF}$ & Atrial Fibrillation \\
\hline 3 & ANP & Atrial Natriuretic Peptide \\
\hline 4 & AUC & Area Under the Curve \\
\hline 5 & BNP & B-type Natriuretic Peptide \\
\hline 6 & CI & Confidence Interval \\
\hline 7 & $\mathrm{CT}$ & Computed Tomography \\
\hline 8 & ED & Emergency Department \\
\hline 9 & EDTA & Ethylenediaminetetraacetic Acid \\
\hline 10 & ELISA & Enzyme-Linked Immunosorbent Assay \\
\hline 11 & FDA & Food and Drug Administration \\
\hline 12 & $\mathrm{HF}$ & Heart Failure \\
\hline 13 & LOD & Limit Of Detection \\
\hline 14 & LTC & Long-Term Care \\
\hline 15 & MAB & Monoclonal Antibody \\
\hline 16 & MRI & Magnetic Resonance Imaging \\
\hline 17 & NIHSS & National Institutes of Health Stroke Scale \\
\hline 18 & NT-proBNP & N-Terminal pro-B-type Natriuretic Peptide \\
\hline 19 & OR & Odds Ratio \\
\hline 20 & POC & Point-Of-Care \\
\hline 21 & $\mathrm{ROC}$ & Receiver Operating Characteristic \\
\hline 22 & TIA & Transient Ischemic Attack \\
\hline 23 & TOAST & Trial of Org 10,172 in Acute Stroke Treatment \\
\hline 24 & $\mathrm{tPA}$ & Tissue Plasminogen Activator \\
\hline
\end{tabular}


Author Contributions: Conceptualization, D.H., R.C.S.S., R.S.M. and A.I.Y.T.; writing一original draft preparation, D.H.; review and editing, R.C.S.S., R.S.M. and A.I.Y.T.; visualization, D.H.; supervision, R.S.M. and A.I.Y.T.; project administration, R.S.M. and A.I.Y.T. All authors have read and agreed to the published version of the manuscript.

Funding: This research was funded by the National Research Foundation (NRF) of Singapore under the Campus for Research Excellence and Technological Enterprise (CREATE) and the Singapore International Graduate Award (SINGA) for supporting D.H.

Conflicts of Interest: The authors declare no potential conflicts of interest with respect to the research, authorship, and/or publication of this article.

\section{References}

1. Strong, K.; Mathers, C.; Bonita, R. Preventing stroke: Saving lives around the world. Lancet Neurol. 2007, 6, 182-187. [CrossRef]

2. Hawkes, M.A.; Rabinstein, A.A. Acute ischemic stroke. In Neurological Emergencies: A Practical Approach; Rabinstein, A.A., Ed.; Springer International Publishing: Cham, Switzerland, 2020; pp. 171-188. [CrossRef]

3. American Heart Association and American Stroke Association Linking Policy. Stroke. 2016. Available online: https://www.stroke.org/en/about-stroke/types-of-stroke (accessed on 1 June 2020).

4. Maldonado, S.T.; Riles, S.T. Stroke and Transient Ischemic Attack. In ACS Surgery: Principles and Practice; WebMD, Inc.: New York, NY, USA, 2007; Volume 6, pp. 1-6.

5. Horgan, N.F.; O'regan, M.; Cunningham, C.J.; Finn, A.M. Recovery after stroke: A 1-year profile. Disabil. Rehabil. 2009, 31, 831-839. [CrossRef]

6. Bhavna, J. Stroke Diagnostics and Therapeutics: Global Markets; BCC Research: Wellesley, MA, USA, 2015.

7. Heron, N.; Kee, F.; Donnelly, M.; Cupples, M.E. Systematic review of rehabilitation programmes initiated within 90 days of a transient ischaemic attack or 'minor'stroke: A protocol. BMJ Open 2015, 5, e007849. [CrossRef] [PubMed]

8. Johnston, S.C.; Rothwell, P.M.; Nguyen-Huynh, M.N.; Giles, M.F.; Elkins, J.S.; Bernstein, A.L.; Sidney, S. Validation and refinement of scores to predict very early stroke risk after transient ischaemic attack. Lancet 2007, 369, 283-292. [CrossRef]

9. Huang, Z.-X.; Lin, X.-L.; Lu, H.-K.; Liang, X.-Y.; Fan, L.-J.; Liu, X.-T. Lifestyles correlate with stroke recurrence in Chinese inpatients with first-ever acute ischemic stroke. J. Neurol. 2019, 266, 1194-1202. [CrossRef]

10. MacKay-Lyons, M.; Gubitz, G.; Giacomantonio, N.; Wightman, H.; Marsters, D.; Thompson, K.; Blanchard, C.; Eskes, G.; Thornton, M. Program of rehabilitative exercise and education to avert vascular events after non-disabling stroke or transient ischemic attack (PREVENT Trial): A multi-centred, randomised controlled trial. BMC Neurol. 2010, 10, 122. [CrossRef] [PubMed]

11. Goldstein, L.B.; Adams, R.; Alberts, M.J.; Appel, L.J.; Brass, L.M.; Bushnell, C.D.; Culebras, A.; Degraba, T.J.; Gorelick, P.B.; Guyton, J.R.; et al. Primary prevention of ischemic stroke: A guideline from the American Heart Association/American Stroke Association Stroke Council: Cosponsored by the Atherosclerotic Peripheral Vascular Disease Interdisciplinary Working Group; Cardiovascular Nursing Council; Clinical Cardiology Council; Nutrition, Physical Activity, and Metabolism Council; and the Quality of Care and Outcomes Research Interdisciplinary Working Group: The American Academy of Neurology affirms the value of this guideline. Stroke 2006, 37, 1583-1633. [CrossRef]

12. Rothwell, P.M.; Coull, A.J.; Silver, L.E.; Fairhead, J.F.; Giles, M.F.; Lovelock, C.E.; Redgrave, J.N.; Bull, L.M.; Welch, S.J.; Cuthbertson, F.C.; et al. Population-based study of event-rate, incidence, case fatality, and mortality for all acute vascular events in all arterial territories (Oxford Vascular Study). Lancet 2005, 366, 1773-1783. [CrossRef]

13. Chen, R.L.; Balami, J.S.; Esiri, M.M.; Chen, L.K.; Buchan, A.M. Ischemic stroke in the elderly: An overview of evidence. Nat. Rev. Neurol. 2010, 6, 256-265. [CrossRef]

14. Warlow, C.P.; van Gijn, J.; Dennis, M.; Wardlaw, J.; Bamford, J.; Hankey, G.; Sandercock, P.; Rinkle, G.; Langhorne, P.; Sudlow, C.; et al. Stroke: Practical Management, 3rd ed.; Blackwell Publishing: Oxford, UK, 2008.

15. Allender, S.; Scarborough, P.; Peto, V.; Rayner, M.; Leal, J.; Luengo-Fernandez, R.; Gray, A. European Cardiovascular Disease Statistics; European Heart Network: Brussels, UK, 2008; pp. 1-112.

16. National Audit Office, Department of Health. Reducing Brain Damage: Faster Access to Better Stroke Care; National Audit Office: London, UK, 2005. 
17. Wojner-Alexandrov, A.W.; Alexandrov, A.V.; Rodriguez, D.; Persse, D.; Grotta, J.C. Houston paramedic and emergency stroke treatment and outcomes study (HoPSTO). Stroke 2005, 36, 1512-1518. [CrossRef]

18. Hacke, W.; Kaste, M.; Bluhmki, E.; Brozman, M.; Davalos, A.; Guidetti, D.; Larrue, V.; Lees, K.R.; Medeghri, Z.; Machnig, T.; et al. Thrombolysis with alteplase 3 to 4.5 hours after acute ischemic stroke. N. Engl. J. Med. 2008, 359, 1317-1329. [CrossRef] [PubMed]

19. Sandercock, P.; Wardlaw, J.M.; Lindley, R.I.; Dennis, M.; Cohen, G.; Murray, G.; Innes, K.; Venables, G.; Czlonkowska, A.; Kobayashi, A.; et al. The benefits and harms of intravenous thrombolysis with recombinant tissue plasminogen activator within $6 \mathrm{~h}$ of acute ischaemic stroke (the third international stroke trial [IST-3]): A randomised controlled trial. Lancet 2012, 379, 2352-2363. [CrossRef] [PubMed]

20. Kuhrij, L.S.; Marang-van de Mheen, P.J.; van den Berg-Vos, R.M.; de Leeuw, F.-E.; Nederkoorn, P.J. Determinants of extended door-to-needle time in acute ischemic stroke and its influence on in-hospital mortality: Results of a nationwide Dutch clinical audit. BMC Neurol. 2019, 19, 265. [CrossRef] [PubMed]

21. National Institute of Neurological Disorders; Stroke rt-PA Stroke Study Group. Tissue Plasminogen Activator for Acute Ischemic Stroke. N. Engl. J. Med. 1995, 333, 1581-1588. [CrossRef] [PubMed]

22. Adams, H.P., Jr.; Del Zoppo, G.; Alberts, M.J.; Bhatt, D.L.; Brass, L.; Furlan, A.; Grubb, R.L.; Higashida, R.T.; Jauch, E.C.; Kidwell, C. Guidelines for the early management of adults with ischemic stroke: A guideline from the American Heart Association/American Stroke Association Stroke Council, Clinical Cardiology Council, Cardiovascular Radiology and Intervention Council, and the Atherosclerotic Peripheral Vascular Disease and Quality of Care Outcomes in Research Interdisciplinary Working Groups: The American Academy of Neurology affirms the value of this guideline as an educational tool for neurologists. Stroke 2007, 38, 1655-1711.

23. Sukumaran, M.; Cantrell, D.R.; Ansari, S.A.; Huryley, M.; Shaibani, A.; Potts, M.B. Stroke patient workflow optimization. Endovasc Today 2019, 18, 46-50.

24. Audebert, H.J.; Saver, J.L.; Starkman, S.; Lees, K.R.; Endres, M. Prehospital stroke care: New prospects for treatment and clinical research. Neurology 2013, 81, 501-508. [CrossRef]

25. Leys, D.; Ringelstein, E.B.; Kaste, M.; Hacke, W. Facilities available in European hospitals treating stroke patients. Stroke 2007, 38, 2985-2991. [CrossRef]

26. Fladt, J.; Meier, N.; Thilemann, S.; Polymeris, A.; Traenka, C.; Seiffge, D.J.; Sutter, R.; Peters, N.; Gensicke, H.; Flückiger, B. Reasons for Prehospital Delay in Acute Ischemic Stroke. J. Am. Heart Assoc. 2019, 8, e013101. [CrossRef]

27. Sharobeam, A.; Jones, B.; Walton-Sonda, D.; Lueck, C.J. Factors delaying intravenous thrombolytic therapy in acute ischaemic stroke: A systematic review of the literature. J. Neurol. 2020, 1-12. [CrossRef]

28. Tai, Y.J.; Yan, B. Minimising time to treatment: Targeted strategies to minimise time to thrombolysis for acute ischaemic stroke. Intern. Med. J. 2013, 43, 1176-1182. [CrossRef] [PubMed]

29. Evenson, K.R.; Rosamond, W.D.; Morris, D.L. Prehospital and in-hospital delays in acute stroke care. Neuroepidemiology 2001, 20, 65-76. [CrossRef] [PubMed]

30. Campbell, B.C.; De Silva, D.A.; Macleod, M.R.; Coutts, S.B.; Schwamm, L.H.; Davis, S.M.; Donnan, G.A. Ischaemic stroke. Nat. Rev. Dis. Prim. 2019, 5, 1-22. [CrossRef] [PubMed]

31. Kidwell, C.S.; Chalela, J.A.; Saver, J.L.; Starkman, S.; Hill, M.D.; Demchuk, A.M.; Butman, J.A.; Patronas, N.; Alger, J.R.; Latour, L.L. Comparison of MRI and CT for detection of acute intracerebral hemorrhage. JAMA 2004, 292, 1823-1830. [CrossRef] [PubMed]

32. Garrison, M.E.; Chou, T.M.; Hyde, G.M.; Schaer, A.K. Methods and Systems for Treatment of Acute Ischemic Stroke. U.S. Patent US20130281788A1, 24 October 2013.

33. Ferro, J.M.; Massaro, A.R.; Mas, J.L. Aetiological diagnosis of ischaemic stroke in young adults. Lancet Neurol. 2010, 9, 1085-1096. [CrossRef]

34. Brott, T.; Adams, H.P., Jr.; Olinger, C.P.; Marler, J.R.; Barsan, W.G.; Biller, J.; Spilker, J.; Holleran, R.; Eberle, R.; Hertzberg, V.; et al. Measurements of acute cerebral infarction: A clinical examination scale. Stroke 1989, 20, 864-870. [CrossRef]

35. Goldstein, L.B.; Bertels, C.; Davis, J.N. Interrater reliability of the NIH stroke scale. Arch. Neurol. 1989, 46, 660-662. [CrossRef]

36. Tamar, A.; Malin, R.; Katharina, S.S. NIHSS is not enough for cognitive screening in acute stroke: A cross-sectional, retrospective study. Sci. Rep. 2020, 10, 534. 
37. Hand, P.J.; Kwan, J.; Lindley, R.I.; Dennis, M.S.; Wardlaw, J.M. Distinguishing between stroke and mimic at the bedside: The brain attack study. Stroke 2006, 37, 769-775. [CrossRef]

38. Hemmen, T.M.; Meyer, B.C.; McClean, T.L.; Lyden, P.D. Identification of nonischemic stroke mimics among 411 code strokes at the University of California, San Diego, Stroke Center. J. Stroke Cerebrovasc. Dis. 2008, 17, 23-25. [CrossRef]

39. Deng, Y.Z.; Reeves, M.J.; Jacobs, B.S.; Birbeck, G.L.; Kothari, R.U.; Hickenbottom, S.L.; Mullard, A.J.; Wehner, S.; Maddox, K.; Majid, A. IV tissue plasminogen activator use in acute stroke: Experience from a statewide registry. Neurology 2006, 66, 306-312. [CrossRef] [PubMed]

40. Watkins, C.L.; Leathley, M.J.; Jones, S.P.; Ford, G.A.; Quinn, T.; Sutton, C.J. Training emergency services' dispatchers to recognise stroke: An interrupted time-series analysis. BMC Health Serv. Res. 2013, 13, 318. [CrossRef] [PubMed]

41. Beal, C.C.; Ogola, G.; Allen, L. Validity and Reliability of the Responses to Ischemic Stroke Symptoms Questionnaire. J. Neurosci. Nurs. 2019, 51, 287-291. [CrossRef] [PubMed]

42. Stroke Prevention and Care in France: Report for the Minister of Health and Sport. 2009. Available online: https://www1.health.gov.au/internet/main/publishing.nsf/Content/For+Health+Professionals-1 (accessed on 1 June 2020).

43. Teo, K.; Slark, J. A systematic review of studies investigating the care of stroke survivors in long-term care facilities. Disabil. Rehabil. 2016, 38, 715-723. [CrossRef]

44. Greenberg, E.; Treger, I.; Ring, H. Post-Stroke Follow-Up at the Rehabilitation Center Outpatient Clinic. Sat 2004, 28, 19.

45. Jauch, E.C.; Lindsell, C.; Broderick, J.; Fagan, S.C.; Tilley, B.C.; Levine, S.R. Association of serial biochemical markers with acute ischemic stroke: The National Institute of Neurological Disorders and Stroke recombinant tissue plasminogen activator Stroke Study. Stroke 2006, 37, 2508-2513. [CrossRef]

46. Glickman, S.W.; Phillips, S.; Anstrom, K.J.; Laskowitz, D.T.; Cairns, C.B. Discriminative capacity of biomarkers for acute stroke in the emergency department. J. Emerg. Med. 2011, 41, 333-339. [CrossRef]

47. Chollet, F.; Albucher, J.-F. Strategies to augment recovery after stroke. Curr. Treat. Options Neurol. 2012, 14, 531-540. [CrossRef]

48. Ng, G.J.L.; Quek, A.M.L.; Cheung, C.; Arumugam, T.V.; Seet, R.C.S. Stroke biomarkers in clinical practice: A critical appraisal. Neurochem. Int. 2017, 107, 11-22. [CrossRef]

49. Simpkins, A.N.; Janowski, M.; Oz, H.S.; Roberts, J.; Bix, G.; Doré, S.; Stowe, A.M. Biomarker Application for Precision Medicine in Stroke. Transl. Stroke Res. 2020, 11, 615-627. [CrossRef]

50. Menosi Gualandro, D.; Twerenbold, R.; Boeddinghaus, J.; Nestelberger, T.; Puelacher, C.; Müller, C. Biomarkers in cardiovascular medicine: Towards precision medicine. Swiss Med. Wkly. 2019, 149, w20125. [CrossRef] [PubMed]

51. Harpaz, D.; Eltzov, E.; Seet, R.; Marks, R.S.; Tok, A.I.Y. Point-of-care-testing in acute stroke management: An unmet need ripe for technological harvest. Biosensors 2017, 7, 30. [CrossRef] [PubMed]

52. Quinn, T.J.; Drozdowska, B.A. Stroke prediction and the future of prognosis research. Nat. Rev. Neurol. 2019, 15, 311-312. [CrossRef] [PubMed]

53. Cata, J.P.; Abdelmalak, B.; Farag, E. Neurological biomarkers in the perioperative period. Br. J. Anaesth. 2011, 107, 844-858. [CrossRef]

54. Seet, R.C.S.; Lee, C.-Y.J.; Chan, B.P.L.; Sharma, V.K.; Teoh, H.-L.; Venketasubramanian, N.; Lim, E.C.H.; Chong, W.-L.; Looi, W.-F.; Huang, S.-H. Oxidative damage in ischemic stroke revealed using multiple biomarkers. Stroke 2011, 42, 2326-2329. [CrossRef]

55. Laskowitz, D.T.; Kasner, S.E.; Saver, J.; Remmel, K.S.; Jauch, E.C. Clinical usefulness of a biomarker-based diagnostic test for acute stroke: The Biomarker Rapid Assessment in Ischemic Injury (BRAIN) study. Stroke 2009, 40, 77-85. [CrossRef]

56. Yokobori, S.; Hosein, K.; Burks, S.; Sharma, I.; Gajavelli, S.; Bullock, R. Biomarkers for the clinical differential diagnosis in traumatic brain injury-A systematic review. CNS Neurosci. Ther. 2013, 19, 556-565. [CrossRef]

57. Mir, I.N.; Chalak, L.F. Serum biomarkers to evaluate the integrity of the neurovascular unit. Early Hum. Dev. 2014, 90, 707-711. [CrossRef]

58. Peplow, P.V.; Martinez, B.; Dambinova, S.A. Stroke Biomarkers; Humana: New York, NY, USA, 2020.

59. Kamtchum-Tatuene, J.; Jickling, G.C. Blood Biomarkers for Stroke Diagnosis and Management. Neuromol. Med. 2019, 21, 344-368. [CrossRef] 
60. Sharp, F.; Jickling, G.C. Biomarkers for the Diagnosis of Lacunar Stroke. U.S. Patent US10196690B2, 5 February 2019.

61. Ford, B.D.; Ford, G. Biomarkers for Stroke. U.S. Patent US20190004065A1, 3 January 2019.

62. Augello, C.J.; Noll, J.M.; Distel, T.J.; Wainright, J.D.; Stout, C.E.; Ford, B.D. Identification of novel blood biomarker panels to detect ischemic stroke in patients and their responsiveness to therapeutic intervention. Brain Res. 2018, 1698, 161-169. [CrossRef]

63. Makris, K.; Haliassos, A.; Chondrogianni, M.; Tsivgoulis, G. Blood biomarkers in ischemic stroke: Potential role and challenges in clinical practice and research. Crit. Rev. Clin. Lab. Sci. 2018, 55, 294-328. [CrossRef] [PubMed]

64. Ng, G.J.; Ng, M.Y.; Quek, A.M.; Seet, R.C. Resolving Difficult Case Scenarios by Incorporating Stroke Biomarkers in Clinical Decision-making. In Acute Brain Impairment: Scientidic Discoveries and Translational Research; Peplow, P.V., Dambinova, S.A., Gennarelli, T.A., Martinez, B., Eds.; Royal Society of Chemistry: London, UK, 2017; pp. 289-314.

65. Misra, S.; Kumar, A.; Kumar, P.; Yadav, A.K.; Mohania, D.; Pandit, A.K.; Prasad, K.; Vibha, D. Blood-based protein biomarkers for stroke differentiation: A systematic review. Proteom. Clin. Appl. 2017, 11, 1700007. [CrossRef] [PubMed]

66. LaMont, J.; Mc Connell, I.; Fitzgerald, P. Biomarker-Based Methods and Biochips for Aiding the Diagnosis of Stroke. U.S. Patent 15/457,297, 29 June 2017.

67. Montaner, J.; Ramiro, L.; Simats, A.; Tiedt, S.; Makris, K.; Jickling, G.C.; Debette, S.; Sanchez, J.-C.; Bustamante, A. Multilevel omics for the discovery of biomarkers and therapeutic targets for stroke. Nat. Rev. Neurol. 2020, 16, 247-264. [CrossRef] [PubMed]

68. Pawluk, H.; Woźniak, A.; Grześk, G.; Kołodziejska, R.; Kozakiewicz, M.; Kopkowska, E.; Grzechowiak, E.; Kozera, G. The Role of Selected Pro-Inflammatory Cytokines in Pathogenesis of Ischemic Stroke. Clin. Interv. Aging 2020, 15, 469. [CrossRef] [PubMed]

69. Liu, K.J.; Liu, W.; Timmins, G.; Pan, R. Blood Biomarker for Early Blood Brain Barrier Disruption in Ischemic Stroke. U.S. Patent US10591491B1, 17 March 2020.

70. Gasiorek, P.; Banach, M.; Sakowicz, A.; Głąbiński, A.; Sosnowska, B.; Maciejewski, M.; Bielecka-Dabrowa, A. The potential role of inflammation in cryptogenic stroke. Adv. Med. Sci. 2019, 64, 381-387. [CrossRef]

71. Lee, N.S.; Daniels, L.B. Natriuretic peptide use in screening in the community. In Cardiac Biomarkers; Springer: Berlin/Heidelberg, Germany, 2016; pp. 181-193.

72. Balion, C.; McKelvie, R.; Don-Wauchope, A.C.; Santaguida, P.L.; Oremus, M.; Keshavarz, H.; Hill, S.A.; Booth, R.A.; Ali, U.; Brown, J.A. B-type natriuretic peptide-guided therapy: A systematic review. Heart Fail. Rev. 2014, 19, 553-564. [CrossRef]

73. Pemberton, C.J.; Charles, C.J.; Richards, A.M. Chapter 1-Cardiac natriuretic peptides. In Endocrinology of the Heart in Health and Disease; Schisler, J.C., Lang, C.H., Willis, M.S., Eds.; Academic Press: Cambridge, MA, USA, 2017; pp. 3-39. [CrossRef]

74. Mukoyama, M.; Nakao, K.; Hosoda, K.; Suga, S.; Saito, Y.; Ogawa, Y.; Shirakami, G.; Jougasaki, M.; Obata, K.; Yasue, H. Brain natriuretic peptide as a novel cardiac hormone in humans. Evidence for an exquisite dual natriuretic peptide system, atrial natriuretic peptide and brain natriuretic peptide. J. Clin. Investig. 1991, 87, 1402-1412. [CrossRef]

75. Fu, S.; Ping, P.; Zhu, Q.; Ye, P.; Luo, L. Brain Natriuretic Peptide and Its Biochemical, Analytical, and Clinical Issues in Heart Failure: A Narrative Review. Front. Physiol. 2018, 9, 692. [CrossRef]

76. Mair, J. Biochemistry of B-type natriuretic peptide-where are we now? Clin. Chem. Lab. Med. 2008, 46, 1507-1514. [CrossRef]

77. Atisha, D.; Bhalla, M.A.; Morrison, L.K.; Felicio, L.; Clopton, P.; Gardetto, N.; Kazanegra, R.; Chiu, A.; Maisel, A.S. A prospective study in search of an optimal B-natriuretic peptide level to screen patients for cardiac dysfunction. Am. Heart J. 2004, 148, 518-523. [CrossRef]

78. Sedlakova, E.; Prusik, Z.; Škopková, J.; Barth, T.; Kluh, I.; Cort, J.H. Isolation of a tridecapeptide from natriuretic fractions of bovine posterior pituitary. Eur. J. Clin. Investig. 1974, 4, 285-292. [CrossRef]

79. Nakagawa, M.; Tanaka, I.; Suga, S.I.; Ogawa, Y.; Tamura, N.; Goto, M.; Sugawara, A.; Yoshimasa, T.; Itoh, H.; Mukoyama, M.; et al. Preparation of a monoclonal antibody against mouse brain natriuretic peptide (BNP) and tissue distribution of BNP in mice. Clin. Exp. Pharmacol. Physiol. 1995, 22, S186-S187. [CrossRef] [PubMed] 
80. Hunt, P.J.; Yandle, T.G.; Nicholls, M.G.; Richards, A.M.; Espiner, E.A. The amino-terminal portion of pro-brain natriuretic peptide (Pro-BNP) circulates in human plasma. Biochem. Biophys. Res. Commun. 1995, 214, 1175-1183. [CrossRef] [PubMed]

81. Cowie, M.R.; Jourdain, P.; Maisel, A.; Dahlstrom, U.; Follath, F.; Isnard, R.; Luchner, A.; McDonagh, T.; Mair, J.; Nieminen, M.; et al. Clinical applications of B-type natriuretic peptide (BNP) testing. Eur. Heart J. 2003, 24, 1710-1718. [CrossRef]

82. De Bold, A.J. Atrial natriuretic factor of the rat heart. Studies on isolation and properties. Proc. Soc. Exp. Biol. Med. 1982, 170, 133-138. [CrossRef] [PubMed]

83. Kambayashi, Y.; Nakao, K.; Mukoyama, M.; Saito, Y.; Ogawa, Y.; Shiono, S.; Inouye, K.; Yoshida, N.; Imura, H. Isolation and sequence determination of human brain natriuretic peptide in human atrium. FEBS Let. 1990, 259, 341-345. [CrossRef]

84. Hino, J.; Tateyama, H.; Minamino, N.; Kangawa, K.; Matsuo, H. Isolation and identification of human brain natriuretic peptides in cardiac atrium. Biochem. Biophys. Res. Commun. 1990, 167, 693-700. [CrossRef]

85. Ala-Kopsala, M.; Ruskoaho, H.; Leppaluoto, J.; Seres, L.; Skoumal, R.; Toth, M.; Horkay, F.; Vuolteenaho, O. Single assay for amino-terminal fragments of cardiac A-and B-type natriuretic peptides. Clin. Chem. 2005, 51, 708-718. [CrossRef]

86. Lewin, J.; Ledwidge, M.; O’Loughlin, C.; McNally, C.; McDonald, K. Clinical deterioration in established heart failure: What is the value of BNP and weight gain in aiding diagnosis? Eur. J. Heart Failure 2005, 7, 953-957. [CrossRef]

87. Kangawa, K.; Matsuo, H. Purification and complete amino acid sequence of $\alpha$-human atrial natriuretic polypeptide ( $\alpha$-hANP). Biochem. Biophys. Res. Commun. 1984, 118, 131-139. [CrossRef]

88. Kambayashi, Y.; Nakao, K.; Itoh, H.; Hosoda, K.; Saito, Y.; Yamada, T.; Mukoyama, M.; Arai, H.; Shirakami, G.; Suga, S.; et al. Isolation and sequence determination of rat cardiac natriuretic peptide. Biochem. Biophys. Res. Commun. 1989, 163, 233-240. [CrossRef]

89. Schellenberger, U.; O'Rear, J.; Guzzetta, A.; Jue, R.A.; Protter, A.A.; Pollitt, N.S. The precursor to B-type natriuretic peptide is an O-linked glycoprotein. Arch. Biochem. Biophys. 2006, 451, 160-166. [CrossRef] [PubMed]

90. Ueda, S.; Sudoh, T.; Fukuda, K.; Kangawa, K.; Minamino, N.; Matsuo, H. Identification of alpha atrial natriuretic peptide and in porcine brain. Biochem. Biophys. Res. Commun. 1987, 149, 1055-1062. [CrossRef]

91. Sudoh, T.; Kangawa, K.; Minamino, N.; Matsuo, H. A new natriuretic peptide in porcine brain. Nature 1988, 332, 78-81. [CrossRef] [PubMed]

92. Kreiger, G. A basic guide to understanding plasma B-type natriuretic peptide in the diagnosis of congestive heart failure. Medsurg Nurs. 2007, 16, 75-79.

93. Ray, P.; Delerme, S.; Jourdain, P.; Chenevier-Gobeaux, C. Differential diagnosis of acute dyspnea: The value of B natriuretic peptides in the emergency department. QJM Int. J. Med. 2008, 101, 831-843. [CrossRef] [PubMed]

94. Andritsos, M.; Singh, N.; Patel, P.; Sinha, A.; Fassl, J.; Wyckoff, T.; Riha, H.; Roscher, C.; Subramaniam, B.; Ramakrishna, H.; et al. The year in cardiothoracic and vascular anesthesia: Selected highlights from 2010. J. Cardiothorac. Vasc. Anesth. 2011, 25, 6-15. [CrossRef]

95. Cowie, M.R. Recent developments in the management of heart failure. Practitioner 2012, 256, 25-30. [CrossRef]

96. Oremus, M.; McKelvie, R.; Don-Wauchope, A.; Santaguida, L.P.; Ali, U.; Balion, C.; Hill, S.; Booth, R.; Brown, A.J.; Bustamam, A.; et al. A systematic review of BNP and NT-proBNP in the management of heart failure: Overview and methods. Heart Fail. Rev. 2014, 19, 413-419. [CrossRef]

97. García-Berrocoso, T.; Giralt, D.; Bustamante, A.; Etgen, T.; Jensen, J.K.; Sharma, J.C.; Shibazaki, K.; Saritas, A.; Chen, X.; Whiteley, W.N.; et al. B-type natriuretic peptides and mortality after stroke. Neurology 2013, 81, 1976-1985. [CrossRef]

98. Shibazaki, K.; Kimura, K. Diagnosis and treatment of acute ischemic stroke. Brain Nerve 2013, 65, $1023-1030$. [PubMed]

99. Jickling, G.C.; Foerch, C. Predicting stroke mortality. Neurology 2013, 81, 1970-1971. [CrossRef] [PubMed]

100. Shibazaki, K.; Kimura, K.; Sakai, K.; Fujii, S.; Aoki, J.; Saji, N. Brain Natriuretic Peptide on Admission as a Biological Marker of Long-Term Mortality in Ischemic Stroke Survivors. Eur. Neurol. 2013, 70, 218-224. [CrossRef] [PubMed] 
101. Chen, X.; Zhan, X.; Chen, M.; Lei, H.; Wang, Y.; Wei, D.; Jiang, X. The prognostic value of combined NT-pro-BNP levels and NIHSS scores in patients with acute ischemic stroke. Intern. Med. 2012, 51, 2887-2892. [CrossRef]

102. Montaner, J.; García-Berrocoso, T.; Mendioroz, M.; Palacios, M.; Perea-Gainza, M.; Delgado, P.; Rosell, A.; Slevin, M.; Ribó, M.; Molina, C.A.; et al. Brain Natriuretic Peptide Is Associated with Worsening and Mortality in Acute Stroke Patients but Adds No Prognostic Value to Clinical Predictors of Outcome. Cerebrovasc. Dis. 2012, 34, 240-245. [CrossRef]

103. Li, J.; Gu, C.; Li, D.; Chen, L.; Lu, Z.; Zhu, L.; Huang, H. Effects of serum N-terminal pro B-type natriuretic peptide and D-dimer levels on patients with acute ischemic stroke. Pak. J. Med Sci. 2018, 34, 994. [CrossRef]

104. Hess, G.; Horsch, A.; Zdunek, D. Troponin and Bnp Based Diagnosis of Risk Patients and Cause of Stroke. U.S. Patent US20180196066A1, 12 July 2018.

105. Tu, W.-J.; Ma, G.-Z.; Ni, Y.; Hu, X.-S.; Luo, D.-Z.; Zeng, X.-W.; Liu, Q.; Xu, T.; Yu, L.; Wu, B. Copeptin and NT-proBNP for prediction of all-cause and cardiovascular death in ischemic stroke. Neurology 2017, 88, 1899-1905. [CrossRef]

106. Sayan, S.; Kotan, D. Levels of brain natriuretic peptide as a marker for the diagnosis and prognosis of acute ischemic stroke. Arch. Med. Sci. Atheroscler. Dis. 2016, 1, e16. [CrossRef]

107. Bunevicius, A.; Kazlauskas, H.; Raskauskiene, N.; Mickuviene, N.; Ndreu, R.; Corsano, E.; Bunevicius, R. Role of N-terminal pro-B-type natriuretic peptide, high-sensitivity C-reactive protein, and inteleukin-6 in predicting a poor outcome after a stroke. Neuroimmunomodulation 2015, 22, 365-372. [CrossRef]

108. Di Castelnuovo, A.; Veronesi, G.; Costanzo, S.; Zeller, T.; Schnabel, R.B.; de Curtis, A.; Salomaa, V.; Borchini, R.; Ferrario, M.; Giampaoli, S. NT-proBNP (N-Terminal Pro-B-Type Natriuretic Peptide) and the Risk of Stroke: Results from the BiomarCaRE Consortium. Stroke 2019, 50, 610-617. [CrossRef]

109. Amarenco, P.; Bogousslavsky, J.; Caplan, L.R.; Donnan, G.A.; Hennerici, M.G. Classification of stroke subtypes. Cerebrovasc. Dis. 2009, 27, 493-501. [CrossRef] [PubMed]

110. Mac Grory, B.; Flood, S.P.; Apostolidou, E.; Yaghi, S. Cryptogenic Stroke: Diagnostic Workup and Management. Curr. Treat. Options Cardiovasc. Med. 2019, 21, 77. [CrossRef]

111. Petty, G.W.; Brown, R.D., Jr.; Whisnant, J.P.; Sicks, J.R.D.; O’Fallon, W.M.; Wiebers, D.O. Ischemic stroke subtypes: A population-based study of incidence and risk factors. Stroke 1999, 30, 2513-2516. [CrossRef] [PubMed]

112. Lodder, J.; Bamford, J.M.; Sandercock, P.A.G.; Jones, L.N.; Warlow, C.P. Are hypertension or cardiac embolism likely causes of lacunar infarction? Stroke 1990, 21, 375-381. [CrossRef]

113. Grau, A.J.; Weimar, C.; Buggle, F.; Heinrich, A.; Goertler, M.; Neumaier, S.; Glahn, J.; Brandt, T.; Hacke, W.; Diener, H.-C. Risk Factors, Outcome, and Treatment in Subtypes of Ischemic Stroke. Ger. Stroke Data Bank 2001, 32, 2559-2566. [CrossRef]

114. Lee, L.J.; Kidwell, C.S.; Alger, J.; Starkman, S.; Saver, J.L. Impact on stroke subtype diagnosis of early diffusion-weighted magnetic resonance imaging and magnetic resonance angiography. Stroke 2000, 31, 1081-1089. [CrossRef]

115. Adams, H.P., Jr.; Bendixen, B.H.; Kappelle, L.J.; Biller, J.; Love, B.B.; Gordon, D.L.; Marsh, E.E., 3rd. Classification of subtype of acute ischemic stroke. Definitions for use in a multicenter clinical trial. TOAST. Trial of Org 10172 in Acute Stroke Treatment. Stroke 1993, 24, 35-41. [CrossRef] [PubMed]

116. Landau, W.M.; Nassief, A. Editorial comment-Time to burn the TOAST. Stroke 2005, 36, 902-904. [CrossRef] [PubMed]

117. Amarenco, P. Patent foramen ovale and the risk of stroke: Smoking gun guilty by association? Heart 2005, 91, 441-443. [CrossRef] [PubMed]

118. Yang, H.-1.; Lin, Y.-P.; Long, Y.; Ma, Q.-1.; Zhou, C. Predicting Cardioembolic Stroke with the B-Type Natriuretic Peptide Test: A Systematic Review and Meta-analysis. J. Stroke Cerebrovasc. Dis. 2014, 23, 1882-1889. [CrossRef] [PubMed]

119. Llombart, V.; Antolin-Fontes, A.; Bustamante, A.; Giralt, D.; Rost Natalia, S.; Furie, K.; Shibazaki, K.; Biteker, M.; Castillo, J.; Rodríguez-Yáñez, M.; et al. B-Type Natriuretic Peptides Help in Cardioembolic Stroke Diagnosis. Stroke 2015, 46, 1187-1195. [CrossRef] [PubMed]

120. Kawase, S.; Kowa, H.; Suto, Y.; Fukuda, H.; Kusumi, M.; Nakayasu, H.; Nakashima, K. Plasma Brain Natriuretic Peptide is a Marker of Prognostic Functional Outcome in Non-Cardioembolic Infarction. J. Stroke Cerebrovasc. Dis. 2015, 24, 2285-2290. [CrossRef] 
121. Wu, Z.; Zhao, M.; He, M.; Zeng, H.; Tan, F.; Li, K.; Chen, S.; Han, Q.; Wang, Q. Validation of the use of B-type natriuretic peptide point-of-care test platform in preliminary recognition of cardioembolic stroke patients in the ED. Am. J. Emerg. Med. 2015, 33, 521-526. [CrossRef]

122. Chaudhuri, J.R.; Sharma, V.K.; Mridula, K.R.; Balaraju, B.; Bandaru, V.C.S.S. Association of Plasma Brain Natriuretic Peptide Levels in Acute Ischemic Stroke Subtypes and Outcome. J. Stroke Cerebrovasc. Dis. 2015, 24, 485-491. [CrossRef] [PubMed]

123. Cojocaru, I.M.; Cojocaru, M.; Sapira, V.; Ionescu, A.; Bârlan, S.; Tacu, N. Could pro-BNP, uric acid, bilirubin, albumin and transferrin be used in making the distinction between stroke subtypes? Rom. J. Intern. Med. 2013, 51, 188-195. [CrossRef] [PubMed]

124. Wu, Z.; Yang, L.; Guo, Q.; He, M.; Li, K. Experiences and the use of BNP POCT platform on suspected ischemic stroke patients in the emergency department setting. Clin. Neurol. Neurosurg. 2014, 123, 199-200. [CrossRef] [PubMed]

125. Hajsadeghi, S.; Kashani Amin, L.; Bakhshandeh, H.; Rohani, M.; Azizian, A.R.; Jafarian Kerman, S.R. The diagnostic value of $\mathrm{N}$-terminal pro-brain natriuretic peptide in differentiating cardioembolic ischemic stroke. J. Stroke Cerebrovasc. Dis. Off. J. Natl. Stroke Assoc. 2013, 22, 554-560. [CrossRef]

126. Kara, K.; Gronewold, J.; Neumann, T.; Mahabadi, A.A.; Weimar, C.; Lehmann, N.; Berger, K.; Kalsch, H.I.; Bauer, M.; Broecker-Preuss, M.; et al. B-type natriuretic peptide predicts stroke of presumable cardioembolic origin in addition to coronary artery calcification. Eur. J. Neurol. 2014, 21, 914-921. [CrossRef]

127. Maruyama, K.; Shiga, T.; Iijima, M.; Moriya, S.; Mizuno, S.; Toi, S.; Arai, K.; Ashihara, K.; Abe, K.; Uchiyama, S. Brain natriuretic peptide in acute ischemic stroke. J. Stroke Cerebrovasc. Dis. Off. J. Natl. Stroke Assoc. 2014, 23, 967-972. [CrossRef]

128. Qihong, G.; Zhixin, W.; Mingfeng, H.; Lianhong, Y.; Wenchong, X. Experiences and the use of BNP POCT platform on suspected stroke patients by a Chinese emergency department. Ann. Indian Acad. Neurol. 2014, 17, 243-244. [CrossRef]

129. Sakai, K.; Shibazaki, K.; Kimura, K.; Aoki, J.; Kobayashi, K.; Fujii, S.; Okada, Y. Brain natriuretic peptide as a predictor of cardioembolism in acute ischemic stroke patients: Brain natriuretic peptide stroke prospective study. Eur. Neurol. 2013, 69, 246-251. [CrossRef] [PubMed]

130. Shibazaki, K.; Kimura, K.; Iguchi, Y.; Okada, Y.; Inoue, T. Plasma brain natriuretic peptide can be a biological marker to distinguish cardioembolic stroke from other stroke types in acute ischemic stroke. Intern. Med. 2009, 48, 259-264. [CrossRef] [PubMed]

131. Ueno, Y.; Tanaka, R.; Yamashiro, K.; Shimada, Y.; Kuroki, T.; Hira, K.; Urabe, T.; Hattori, N. Impact of BNP on cryptogenic stroke without potential embolic sources on transesophageal echocardiography. J. Neurol. Sci. 2015, 359, 287-292. [CrossRef] [PubMed]

132. Otaki, Y.; Watanabe, T.; Sato, N.; Shirata, T.; Tsuchiya, H.; Wanezaki, M.; Tamura, H.; Nishiyama, S.; Arimoto, T.; Takahashi, H. Direct comparison of prognostic ability of cardiac biomarkers for cardiogenic stroke and clinical outcome in patients with stroke. Heart Vessel. 2019, 34, 1178-1186. [CrossRef] [PubMed]

133. Bai, J.; Sun, H.; Xie, L.; Zhu, Y.; Feng, Y. Detection of cardioembolic stroke with B-type natriuretic peptide or N-terminal pro-BNP: A comparative diagnostic meta-analysis. Int. J. Neurosci. 2018, 128, 1100-1108. [CrossRef] [PubMed]

134. Lee, S.-J.; Lee, D.-G.; Lim, D.-S.; Hong, S.; Park, J.-S. Difference in the prognostic significance of N-terminal pro-B-type natriuretic peptide between cardioembolic and noncardioembolic ischemic strokes. Dis. Markers 2015, 2015, 597570. [CrossRef]

135. Nakamura, M.; Ishibashi, Y.; Tanaka, F.; Omama, S.; Onoda, T.; Takahashi, T.; Takahashi, S.; Tanno, K.; Ohsawa, M.; Sakata, K. Ability of B-Type Natriuretic Peptide Testing to Predict Cardioembolic Stroke in the General Population-Comparisons with C-Reactive Protein and Urinary Albumin-. Circ. J. 2018, 82, 1017-1025. [CrossRef]

136. Zhixin, W.U.; Yingying, L.I.; Liang, S.; Qing, F.; Lei, J.; Chen, J.; Mingfeng, H.E.; Kuangyi, L.I. The value of using B-type natriuretic peptide and D-dimer in preliminary recognition of cardioembolic stroke patients. J. Pract. Med. 2018, 34, 44-48.

137. Lee, S.-J.; Lee, D.-G.; Chung, T.-I. N-terminal pro-B-type natriuretic peptide predicts long-term mortality but not stroke recurrence in acute ischemic stroke patients with a cardioembolic source (P1. 051). Neurology 2015, 84 (Suppl. S14), P1.051. 
138. Hosomi, N.; Yoshimoto, T.; Kanaya, Y.; Neshige, S.; Hara, N.; Himeno, T.; Kono, R.; Takeshima, S.; Takamatsu, K.; Ota, T. Brain natriuretic peptide and particular left ventricle segment asynergy associated with cardioembolic stroke from old myocardial infarction. J. Stroke Cerebrovasc. Dis. 2016, 25, 1165-1171. [CrossRef]

139. Mohamed, W.S.; Abd ElGawad, E.A.; ElMotayam, A.S.E.; Fathy, S.E. Cardio embolic stroke and blood biomarkers: Diagnosis and predictors of short-term outcome. Egypt. J. Neurol. Psychiatry Neurosurg. 2019, 55, 68. [CrossRef]

140. Okada, Y.; Terakawa, Y.; Murata, T.; Nakamura, K.; Shimotake, K.; Murata, H.; Ohata, K. Ability of NT-pro-BNP to Diagnose Cardioembolic Etiology in Patients with Acute Ischemic Stroke. Osaka City Med. J. 2016, 62, 95-102.

141. Inoue, S.; Murakami, Y.; Sano, K.; Katoh, H.; Shimada, T. Atrium as a source of brain natriuretic polypeptide in patients with atrial fibrillation. J. Card Fail. 2000, 6, 92-96. [CrossRef]

142. Shibazaki, K.; Kimura, K.; Aoki, J.; Sakai, K.; Saji, N.; Uemura, J. Brain natriuretic peptide level on admission predicts recurrent stroke after discharge in stroke survivors with atrial fibrillation. Clin. Neurol. Neurosurg. 2014, 127, 25-29. [CrossRef] [PubMed]

143. Shibazaki, K.; Kimura, K.; Aoki, J.; Sakai, K.; Saji, N.; Uemura, J. Plasma Brain Natriuretic Peptide as a Predictive Marker of Early Recurrent Stroke in Cardioembolic Stroke Patients. J. Stroke Cerebrovasc. Dis. 2014, 23, 2635-2640. [CrossRef] [PubMed]

144. Mortezabeigi, H.R.; Taghizadeh, A.; Talebi, M.; Amini, K.; Goldust, M. ABCD2 score and BNP level in patients with TIA and cerebral stroke. Pak. J. Biol. Sci. 2013, 16, 1393-1397. [CrossRef]

145. Rodríguez-Castro, E.; Hervella, P.; López-Dequidt, I.; Arias-Rivas, S.; Santamaría-Cadavid, M.; López-Loureiro, I.; da Silva-Candal, A.; Pérez-Mato, M.; Sobrino, T.; Campos, F. NT-pro-BNP: A novel predictor of stroke risk after transient ischemic attack. Int. J. Cardiol. 2020, 298, 93-97. [CrossRef]

146. Cummins, B.M.; Ligler, F.S.; Walker, G.M. Point-of-care diagnostics for niche applications. Biotechnol. Adv. 2016, 34, 161-176. [CrossRef]

147. Yoo, E.H.; Lee, S.Y. Glucose biosensors: An overview of use in clinical practice. Sensors 2010, 10, 4558-4576. [CrossRef]

148. Vasan, A.S.; Mahadeo, D.M.; Doraiswami, R.; Huang, Y.; Pecht, M. Point-of-care biosensor system. Front. Biosci. 2013, 5, 39-71. [CrossRef]

149. Shah, D.; Maghsoudlou, D. Enzyme-linked immunosorbent assay (ELISA): The basics. Br. J. Hosp. Med. 2016, 77, C98-C101. [CrossRef]

150. Price, C.P. Point of care testing. BMJ Br. Med J. 2001, 322, 1285-1288. [CrossRef] [PubMed]

151. Drain, P.K.; Hyle, E.P.; Noubary, F.; Freedberg, K.A.; Wilson, D.; Bishai, W.R.; Rodriguez, W.; Bassett, I.V. Diagnostic point-of-care tests in resource-limited settings. Lancet Infect. Dis. 2014, 14, 239-249. [CrossRef]

152. Thevenot, D.R.; Toth, K.; Durst, R.A.; Wilson, G.S. Electrochemical biosensors: Recommended definitions and classification. Biosens. Bioelectron. 2001, 16, 121-131. [CrossRef] [PubMed]

153. Eltzov, E.; Cosnier, S.; Marks, R.S. Biosensors based on combined optical and electrochemical transduction for molecular diagnostics. Expert. Rev. Mol. Diagn. 2011, 11, 533-546. [CrossRef] [PubMed]

154. Eltzov, E.; Marks, R.S. Whole-cell aquatic biosensors. Anal. Bioanal. Chem. 2011, 400, 895-913. [CrossRef]

155. St John, A.; Price, C.P. Existing and Emerging Technologies for Point-of-Care Testing. Clin. Biochem. Rev. 2014, 35, 155-167.

156. Chin, C.D.; Linder, V.; Sia, S.K. Commercialization of microfluidic point-of-care diagnostic devices. Lab. Chip 2012, 12, 2118-2134. [CrossRef]

157. Paul, S. Biomedical Engineering and Its Applications in Healthcare; Springer: Berlin/Heidelberg, Germany, 2019.

158. McMullan, J.T.; Knight, W.A.; Clark, J.F.; Beyette, F.R.; Pancioli, A. Time-critical neurological emergencies: The unfulfilled role for point-of-care testing. Int. J. Emerg. Med. 2010, 3, 127-131. [CrossRef]

159. Rooney, K.D.; Schilling, U.M. Point-of-care testing in the overcrowded emergency department-Can it make a difference? Crit. Care 2014, 18, 692. [CrossRef]

160. Harpaz, D.; Eltzov, E.; Seet, R.C.S.; Marks, R.S.; Tok, A.I.Y. Rapid Point-of-Care-Tests for Stroke Monitoring. Org. Bioelectron. Life Sci. Healthc. 2019, 56, 263-314.

161. Ala-Kopsala, M.; Moilanen, A.-M.; Rysä, J.; Ruskoaho, H.; Vuolteenaho, O. Characterization of Molecular Forms of N-Terminal B-Type Natriuretic Peptide in Vitro. Clin. Chem. 2010, 56, 1822-1829. [CrossRef] [PubMed] 
162. Ordonez-Llanos, J.; Collinson, P.O.; Christenson, R.H. Amino-Terminal Pro-B-Type Natriuretic Peptide: Analytic Considerations. Am. J. Cardiol. 2008, 101 (Suppl. S3), S9-S15. [CrossRef] [PubMed]

163. Apple, F.S.; Panteghini, M.; Ravkilde, J.; Mair, J.; Wu, A.H.B.; Tate, J.; Pagani, F.; Christenson, R.H.; Jaffe, A.S. Quality Specifications for B-Type Natriuretic Peptide Assays. Clin. Chem. 2005, 51, 486-493. [CrossRef]

164. Clerico, A.; Emdin, M. Diagnostic Accuracy and Prognostic Relevance of the Measurement of Cardiac Natriuretic Peptides: A Review. Clin. Chem. 2004, 50,33-50. [CrossRef]

165. Apple, F.S. Standardization of Cardiac Markers. Scand. J. Clin. Lab. Investig. 2005, 65, 107-111. [CrossRef]

166. Sinawang, P.D.; Harpaz, D.; Fajs, L.; Seet, R.C.S.; Tok, A.I.Y.; Marks, R.S. Electrochemical impedimetric detection of stroke biomarker NT-proBNP using disposable screen-printed gold electrodes. Eurobiotech. J. 2017, 1, 165-176. [CrossRef]

167. Harpaz, D.; Koh, B.; Marks, R.S.; Seet, R.; Abdulhalim, I.; Tok, A.I.Y. Point-of-Care surface plasmon resonance biosensor for stroke biomarkers NT-proBNP and $S 100 \beta$ using a functionalized gold chip with specific antibody. Sensors 2019, 19, 2533. [CrossRef]

168. Harpaz, D.; Koh, B.; Seet, R.C.S.; Abdulhalim, I.; Tok, A.I.Y. Functionalized silicon dioxide self-referenced plasmonic chip as point-of-care biosensor for stroke biomarkers NT-proBNP and S100ß. Talanta 2020, 212, 120792. [CrossRef]

169. Hunt, P.; Espiner, E.; Nicholls, M.; Richards, A.; Yandle, T. The role of the circulation in processing pro-brain natriuretic peptide (proBNP) to amino-terminal BNP and BNP-32. Peptides 1997, 18, 1475-1481. [CrossRef]

170. Goetze, J.P. Biochemistry of pro-B-type natriuretic peptide-derived peptides: The endocrine heart revisited. Clin. Chem. 2004, 50, 1503-1510. [CrossRef] [PubMed]

171. Seferian, K.R.; Tamm, N.N.; Semenov, A.G.; Tolstaya, A.A.; Koshkina, E.V.; Krasnoselsky, M.I.; Postnikov, A.B.; Serebryanaya, D.V.; Apple, F.S.; Murakami, M.M. Immunodetection of glycosylated NT-proBNP circulating in human blood. Clin. Chem. 2008, 54, 866-873. [CrossRef]

172. Ala-Kopsala, M.; Magga, J.; Peuhkurinen, K.; Leipälä, J.; Ruskoaho, H.; Leppaluoto, J.; Vuolteenaho, O. Molecular heterogeneity has a major impact on the measurement of circulating N-terminal fragments of A-and B-type natriuretic peptides. Clin. Chem. 2004, 50, 1576-1588. [CrossRef] [PubMed]

173. Hughes, D.; Talwar, S.; Squire, I.B.; Davies, J.E.; Ng, L.L. An immunoluminometric assay for N-terminal pro-brain natriuretic peptide: Development of a test for left ventricular dysfunction. Clin. Sci. 1999, 96, 373-380. [CrossRef] [PubMed]

174. Karl, J.; Borgya, A.; Gallusser, A.; Huber, E.; Krueger, K.; Rollinger, W.; Schenk, J. Development of a novel, N-terminal-proBNP (NT-proBNP) assay with a low detection limit. Scand. J. Clin. Lab. Investig. 1999, 59, 177-181. [CrossRef]

175. Campbell, D.J.; Mitchelhill, K.I.; Schlicht, S.M.; Booth, R.J. Plasma amino-terminal pro-brain natriuretic peptide: A novel approach to the diagnosis of cardiac dysfunction. J. Card. Fail. 2000, 6, 130-139. [CrossRef]

176. Squire, I.B.; O’Brien, R.J.; Demme, B.; Davies, J.E.; Ng, L.L. N-terminal pro-atrial natriuretic peptide (N-ANP) and N-terminal pro-B-type natriuretic peptide (N-BNP) in the prediction of death and heart failure in unselected patients following acute myocardial infarction. Clin. Sci. 2004, 107, 309-316. [CrossRef]

177. Goetze, J.P.; Kastrup, J.; Pedersen, F.; Rehfeld, J.F. Quantification of pro-B-type natriuretic peptide and its products in human plasma by use of an analysis independent of precursor processing. Clin. Chem. 2002, 48, 1035-1042. [CrossRef]

178. Mueller, T.; Gegenhuber, A.; Poelz, W.; Haltmayer, M. Comparison of the Biomedica NT-proBNP enzyme immunoassay and the Roche NT-proBNP chemiluminescence immunoassay: Implications for the prediction of symptomatic and asymptomatic structural heart disease. Clin. Chem. 2003, 49, 976-979. [CrossRef]

179. Hammerer-Lercher, A.; Ludwig, W.; Falkensammer, G.; MuLler, S.; Neubauer, E.; Puschendorf, B.; Pachinger, O.; Mair, J. Natriuretic peptides as markers of mild forms of left ventricular dysfunction: Effects of assays on diagnostic performance of markers. Clin. Chem. 2004, 50, 1174-1183. [CrossRef]

180. Tamm, N.N.; Seferian, K.R.; Semenov, A.G.; Mukharyamova, K.S.; Koshkina, E.V.; Krasnoselsky, M.I.; Postnikov, A.B.; Serebryanaya, D.V.; Apple, F.S.; Murakami, M.M. Novel immunoassay for quantification of brain natriuretic peptide and its precursor in human blood. Clin. Chem. 2008, 54, 1511-1518. [CrossRef] [PubMed]

181. Tetin, S.Y.; Ruan, Q.; Saldana, S.C.; Pope, M.R.; Chen, Y.; Wu, H.; Pinkus, M.S.; Jiang, J.; Richardson, P.L. Interactions of two monoclonal antibodies with BNP: High resolution epitope mapping using fluorescence correlation spectroscopy. Biochemistry 2006, 45, 14155-14165. [CrossRef] [PubMed] 
182. Balion, C.; Don-Wauchope, A.; Hill, S.; Santaguida, P.L.; Booth, R.; Brown, J.A.; Oremus, M.; Ali, U.; Bustamam, A.; Sohel, N. Use of Natriuretic Peptide Measurement in the Management of Heart Failure; Agency for Healthcare Research and Quality: Rockville, MD, USA, 2013.

183. Maalouf, R.; Bailey, S. A review on B-type natriuretic peptide monitoring: Assays and biosensors. Heart Fail. Rev. 2016, 21, 567-578. [CrossRef] [PubMed]

184. Del Ry, S.; Giannessi, D.; Clerico, A. Plasma brain natriuretic peptide measured by fully-automated immunoassay and by immunoradiometric assay compared. Clin. Chem. Lab. Med. 2001, 39, 446-450.

185. Clerico, A.; Iervasi, G.; Del Chicca, M.G.; Emdin, M.; Maffei, S.; Nannipieri, M.; Sabatino, L.; Forini, F.; Manfredi, C.; Donato, L. Circulating levels of cardiac natriuretic peptides (ANP and BNP) measured by highly sensitive and specific immunoradiometric assays in normal subjects and in patients with different degrees of heart failure. J. Endocrinol. Investig. 1998, 21, 170-179. [CrossRef]

186. Fellner, S.; Hentze, S.; Kempin, U.; Richter, E.; Rocktäschel, J.; Langer, B. Analytical evaluation of a BNP assay on the new point-of-care platform respons ${ }^{\circledR}$ IQ. Pract. Lab. Med. 2015, 2, 15-21. [CrossRef]

187. Ishida, J.; Suzuki, T.; Aizawa, K.; Sawaki, D.; Nagai, R. Comparison of analytical performance of two single-step measurement devices of B-type natriuretic peptide. Int. Heart J. 2012, 53, 320-323. [CrossRef]

188. Yasukawa, K.; Hisajima, K.; Imai, K.; Soga, Y. Introduction of Rapidtip BNP and Rapidpia-A clinical significance of rapid measurement BNP for home medicine care. Gan Kagaku Ryoho. Cancer Chemother. 2009, $36,135-137$.

189. Denny, N.; Lasserson, D.; Price, P.C.; Heneghan, C.; Thompson, M.; Plüddemann, A. Diagnostic Technology: Point of Care B-Type Natriuretic Peptide Testing; The School for Primary Care Research Is a Partnership between the Universities of Birmingham, Bristol, Manchester and Oxford and Is Part of the National Institute for Health Research; Primary Care Diagnostic Horizon Scanning Centre Oxford: Oxford, UK, 2011. Available online: https://www.community.healthcare.mic.nihr.ac.uk/files/reports-and-resources/horizonscanning-report0019-bnp.pdf (accessed on 1 June 2020).

(C) 2020 by the authors. Licensee MDPI, Basel, Switzerland. This article is an open access article distributed under the terms and conditions of the Creative Commons Attribution (CC BY) license (http://creativecommons.org/licenses/by/4.0/). 